INSTITUTO SUPERIOR ANÍSIO TEIXEIRA

Thamires dos Passos Correa

A TRADUÇÃo INTRALINGUAL E A SOCIOLINGUÍSTICA: UMA ANÁLISE DA SÉRIE SINTONIA.

São Gonçalo - RJ

2020 
Thamires dos Passos Correa

\section{A TRADUÇÃO INTRALINGUAL E A SOCIOLINGUÍSTICA: UMA ANÁLISE DA SÉRIE SINTONIA.}

Monografia apresentada à Coordenação do curso de Graduação em Letras/Tradução Português-Inglês do Instituto Superior Anísio Teixeira - ISAT como requisito parcial à obtenção do título de Bacharel em Tradução Português-Inglês.

Orientador (a): Prof. M. ${ }^{e}$ Emanuelle de Souza Fonseca

São Gonçalo - Rj 


\section{A TRADUÇÃO INTRALINGUAL E A SOCIOLINGUÍSTICA: UMA ANÁLISE DA SÉRIE SINTONIA.}

Monografia apresentada à Coordenação do curso de Graduação em Letras/Tradução Português-Inglês do Instituto Superior Anísio Teixeira - ISAT como requisito parcial à obtenção do título de Bacharel em Tradução Português-Inglês.

Orientador (a): Prof. M. ${ }^{e}$ Emanuelle de Souza Fonseca

M. ${ }^{\mathrm{e}}$ Emanuelle de Souza Fonseca - ISAT

São Gonçalo, RJ, 1 de Setembro de 2020 


\section{DEDICATÓRIA}

À minha mãe Marilene. 


\section{AGRADECIMENTOS}

Agradeço primeiramente a Deus por ter me capacitado com sabedoria, me dado forças para prosseguir e realizar os meus sonhos, sem ele nada seria possível.

Aos meus pais, principalmente a minha mãe que me proporcionou essa vida acadêmica sem ela não teria conseguido permanecer na faculdade. Por todo apoio tanto emocional quanto financeiramente. sonhos.

À minha Família Passos que sempre me incentivaram a prosseguir com meus

Ao meu padrinho Eduardo Barcelos que me incentivou a fazer o curso de idiomas da língua inglesa.

Ao meu melhor amigo Yuri por me incentivar e não me deixar desistir.

Às minhas colegas Lorena Leite e Luana Figueiredo por dividirem a vida acadêmica comigo e tornar os dias letivos menos estressantes e mais divertidos.

À minha amiga Carolina Lopes por ter aguentado as minhas crises de ansiedade e por me ajudar nas revisões do trabalho.

À minha amiga Beatriz Quintão pelo todo apoio emocional durante todo o processo da monografia e por não me deixar desistir.

A todos os professores do ISAT que colaboram na minha formação profissional e por me incentivarem a nunca desistir dos meus sonhos.

Agradeço muito a minha orientadora $\mathrm{M}^{\mathrm{e}}$ Emanuelle Souza por ter acreditado em mim e no meu projeto. Além de ser uma grande profissional é excelente como ser humano, uma amiga que a faculdade me presenteou. Sempre me incentivou a não desistir, me acolheu nas crises de ansiedade com todo seu amor e carinho sem o seu apoio não chegaria aonde cheguei. Muitíssimo Obrigada! 
A língua determina

a maneira como as pessoas

percebem e organizam o mundo.

Hipótese de Sapir-Whorf 


\section{RESUMO}

A Tradução tornou-se primordial para a sociedade, principalmente, com o rápido avanço da globalização. Antigamente, as grandes civilizações precisavam do uso de tradutores para que houvesse comunicação entre si, para fins comerciais e políticos. Por conseguinte, nos dias atuais a Tradução continua exercendo um papel importante para a sociedade; devido à Tradução foi possível ter acesso a outras culturas por meio da música, livros, filmes etc. É exigido do tradutor o conhecimento aprofundado tanto da língua-fonte quanto da língua-meta e, além disso, um conhecimento sobre as variações da língua-fonte que podem interferir no trabalho do tradutor. Este trabalho tem como objeto de estudo refletir sobre as possíveis variações linguísticas presentes nos personagens da Série "Sintonia" através da Sociolinguística Variacionista e como essas variações podem interferir no trabalho do tradutor, principalmente o iniciante, por meio da Tradução Intralingual.

Palavras-chave: variações linguísticas. Sintonia. sociolinguística variacionista. tradução intralingual. 


\begin{abstract}
Translation has become paramount for society, especially with the fast advance of globalization. In the past, great civilizations needed the use of translators in order to communicate with each other, for commercial and political purposes. Consequently, today, Translation continues to play an important role for society; due to Translation it was possible to have access to other cultures through music, books, films, etc. Indepth knowledge of both the source and target languages is required of the translator and, in addition, knowledge of variations in the source language that may interfere with the translator's work. This work has as object of study to reflect on the possible linguistic variations present in the characters of the Series "Sintonia" through Variationist Sociolinguistics and how these variations can interfere in the work of the translator, especially the beginner, through Intralingual Translation.
\end{abstract}

Key words: linguistic variations. Sintonia. variationist sociolinguistics. intralingual translation. 


\section{LISTA DE QUADROS}

Quadro 1 - Exemplo da transcrição das cenas ............................................. 48

Quadro 2 - Transcrição da cena 1 ................................................................ 50

Quadro 3 - Transcrição da cena 2 ....................................................... 51

Quadro 4 - Transcrição da cena 3 ...................................................... 52

Quadro 5 - Faixa etária dos entrevistados .................................................... 55

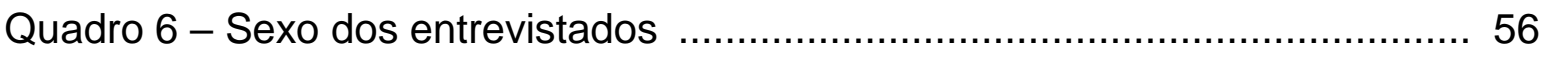

Quadro 7 - Escolaridade dos entrevistados ……….................................. 56

Quadro 8 - Profissão dos entrevistados ..................................................... 57

Quadro 9 - Região dos entrevistados ................................................... 57

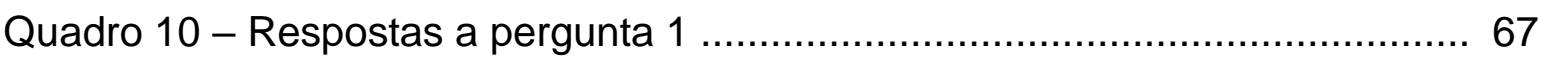

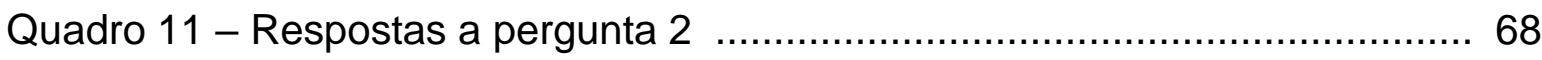

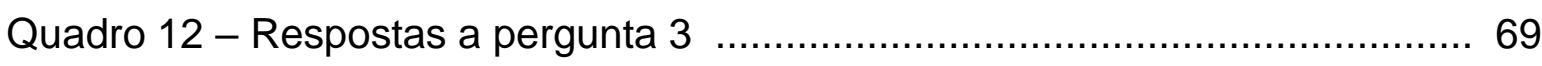

Quadro 13 - Respostas a pergunta 4 ..................................................... 70 


\section{LISTA DE TABELAS}

Tabela 1 - Representação das expressões e das gírias.................................. 54

Tabela 2 - Expressões e gírias do Entrevistado 1 ........................................ 58

Tabela 3 - Expressões e gírias do Entrevistado 2 …………………............. 59

Tabela 4 - Expressões e gírias do Entrevistado 3 .........................................6 60

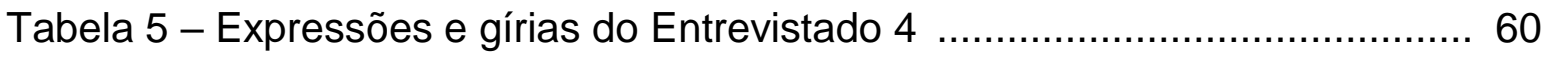

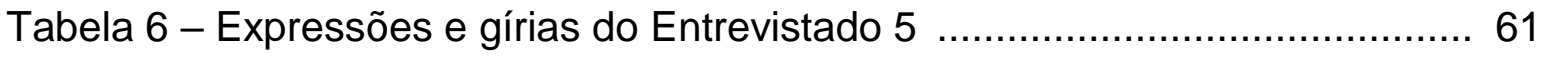

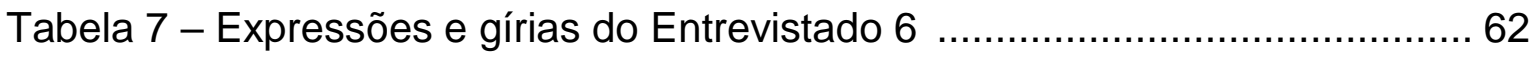

Tabela 8 - Expressões e gírias do Entrevistado 7 ......................................... 63

Tabela 9 - Expressões e gírias do Entrevistado 8 ......................................... 64

Tabela 10 - Expressões e gírias do Entrevistado 9 ...........................................64 64 


\section{LISTA DE SIGLAS}

ONU - Organização das Nações Unidas

LO - Língua de origem

LF - Língua-fonte

LP - Língua de partida

LA - Língua-alvo

LM - Língua-meta

LC - Língua de chegada

T1:E1 - Temporada 1 episódio 1

PT - Português

PT-BR - Português-Brasil

LI - Língua Inglesa

RJ - Rio de Janeiro

BA - Bahia

SP - São Paulo

E - Entrevistado

E1 - Entrevistado 1

E2 - Entrevistado 2

E3 - Entrevistado 3

E4 - Entrevistado 4

E5 - Entrevistado 5

E6 - Entrevistado 6

E7 - Entrevistado 7

E8 - Entrevistado 8

E9 - Entrevistado 9 
2 HISTÓRIA DA TRADUÇÃO

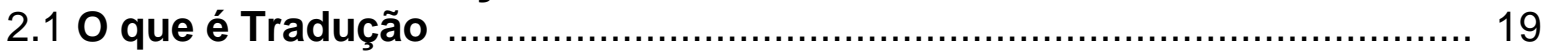

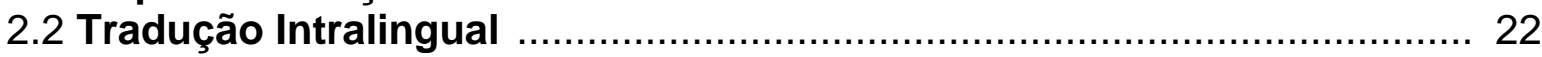

2.2.1 Tradução Literal VS Livre .............................................................. 24

2.2.2 O papel do Tradutor .................................................................... 25

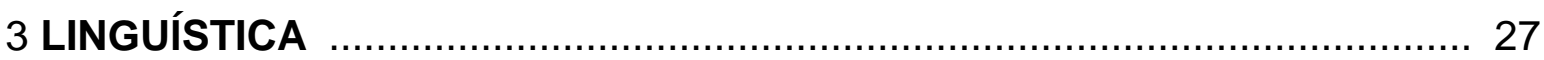

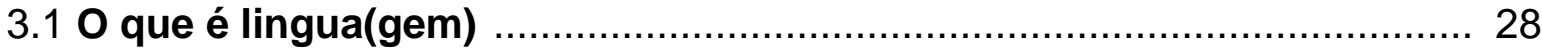

3.1.1 Língua e Cultura .............................................................................. 32

3.2 Sociolinguística Variacionista ..................................................... 34

3.2.1 As Variações Linguísticas ........................................................... 36

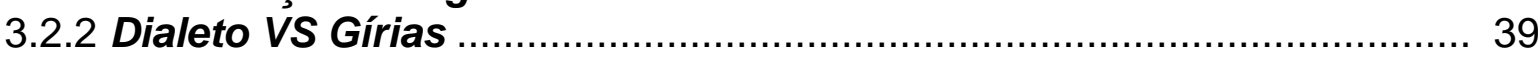

3.2.3 O papel do Sociolinguista .................................................................. 42

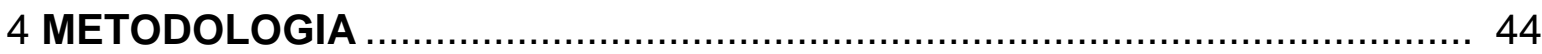

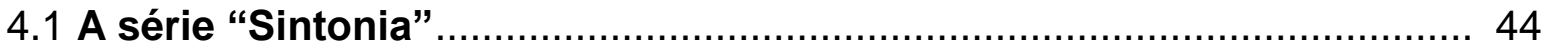

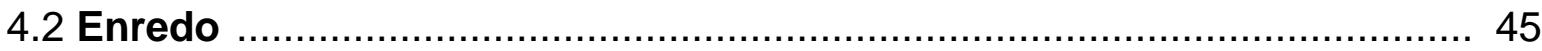

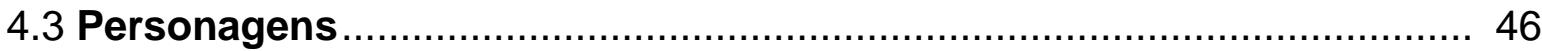

5 ANÁLISE DAS CENAS DA SÉRIE “SINTONIA” ..................................... 49

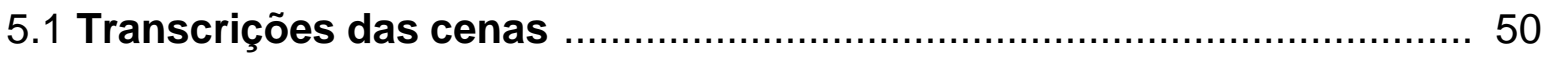

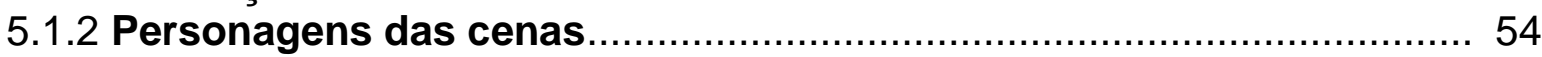

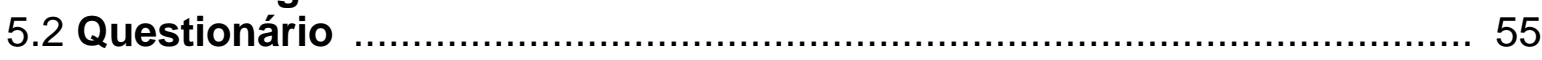

5.2.1 Contexto do Questionário .......................................................... 56

5.2.2 Tabela das expressões e gírias....................................................... 58

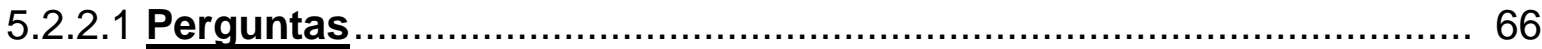

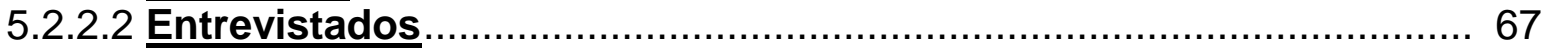

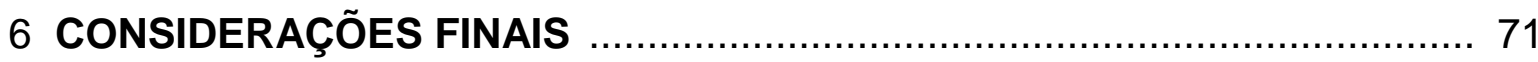

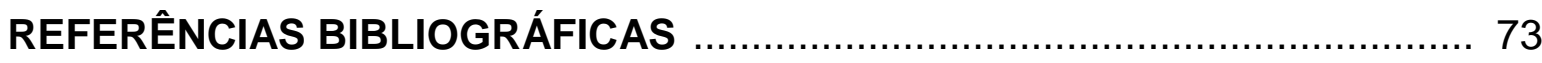

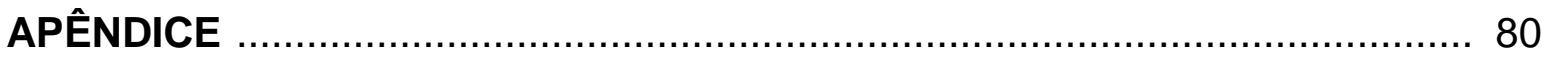




\section{INTRODUÇÃO}

Antigamente, a Tradução era usada, principalmente a fins comerciais e políticos. Contudo, com a globalização este cenário sofreu profundas transformações. A Tradução proporcionou o intercâmbio das culturas por meio da música, livros, filmes e, dentre outros meios.

A partir disso, algumas crenças passaram acompanhar a Tradução e o papel do tradutor. Era-se comum crer que para se tornar um tradutor necessitava apenas o conhecimento da língua-fonte e da língua-meta e ter um dicionário como uma ferramenta de auxílio. "A tradução é uma atividade prática que requer apenas um conhecimento da língua e um bom dicionário". (PAGANO, 2003, p.12).

A fim de alcançar os objetivos para desconstruir essa crença, foi necessário um embasamento na história da Tradução. A fundamentação teórica está sendo de suma importância para a realização desta pesquisa a qual tem a pretensão de correlacionar a Tradução Intralingual com a Sociolinguística Variacionista tendo como base a Série "Sintonia".

Além de pensar nesses requisitos, também é preciso ficar atento em qual tipo de Tradução irá ser realizada, ou seja, se é uma entre línguas diferentes - a Interlingual - ou se é na mesma língua - a Intralingual. Essas informações precisam ser avaliadas antes durante o processo tradutório, devido à diferença cultural existente tanto em línguas diferentes, quanto na mesma língua. Assim, é o tradutor que ficará responsável por fazer essa pesquisa de corpus ao analisar quais termos usados serão adequados numa determinada Tradução.

È correto afirmar que a Tradução e a Linguística se relacionam entre si,visto que as duas têm como objeto de estudo a língua. Todavia, na tradução, normalmente, pesquisa-se o produto, ou seja, o texto que irá ser traduzido e a sua relação com o texto original. Klein $(1992$, p.107) diz que a diferença para a Linguística está exatamente nesse ponto. Enquanto, na Linguística se atenta para declarações prontas, assim, poderá então tirar conclusões de como a linguagem funciona numa comunicação. Já na tradução, ao contrário, a base de estudo é a relação sistemática entre dois textos, da língua-fonte e da língua-meta, que deveriam, por um lado, ser iguais e, por outro (quanto aos meios), não. 
A língua é passível de variações o que dificulta o processo tradutório do tradutor. A Sociolinguística Variacionista, uma das subáreas da Linguística conceituada por Labov (2008), investiga as variações linguísticas por meio da interação social de seus falantes. Conforme Mollica:

"A Sociolinguística é "uma das subáreas da Linguística e estuda a língua em
uso no seio das comunidades de fala, voltando a atenção para um tipo de
investigação que correlaciona aspectos linguísticos e sociais". (2003, p. 9).

Dessa forma, esta pesquisa tem a intenção de tecer uma reflexão sobre os desafios que o tradutor iniciante irá encontrar. Como por exemplo, dos reveses em traduzir a legenda dentro de uma mesma língua. Já que há uma variação linguística dentro de cada vernáculo e cabe ao tradutor analisar todo o corpus antes de traduzir. Gerando assim, informações sobre a língua-fonte e a língua-meta da legenda.

A Tradução Intralingual não é algo muito conhecido pela população - até mesmo para os tradutores iniciantes. Por conseguinte, o presente trabalho levantará a questão de que esse tipo de Tradução está mais presente no nosso dia a dia do que imaginávamos, e que ela é necessária para que possamos compreender as diversidades existentes dentro de uma determinada região. No caso desta pesquisa, discuto sobre a variação linguística do português falado no Brasil e como esta dificulta o tradutor no processo de gerar informações para a Tradução. Assim, seguem os objetivos gerais e específicos do presente trabalho:

Objetivos gerais:

- Analisar o conteúdo linguístico, sócio e cultural da Série "Sintonia" por meio da Tradução Intralingual e da Sociolinguística Variacionista.

- Apontar que há uma relação estreita entre as duas áreas - uma se correlaciona com a outra - visto que ambas estudam a língua.

Objetivos específicos:

- Fazer uma reflexão sobre as possíveis diferenças na linguagem (o regionalismo, a cultura, o social, dentre outros) em ambas as partes analisadas.

- Analisar, primeiramente, a questão da Sociolinguística Variacionista em relação aos personagens da Série "Sintonia". 
- Apresentar a diferença entre o dialeto de uma favela na região de São Paulo e outras do Rio de Janeiro e da Bahia por meio de um questionário realizado com moradores que irá contribuir para a pesquisa que foi baseada na Tradução Intralingual - além de mostrar as diferenças nas variedades linguísticas em ambas as regiões.

O capítulo 2 deste trabalho apresenta a história da Tradução, o começo de tudo e, além disso, o porquê foi e é tão necessário o uso da Tradução para a sociedade. Ademais, mostra as diferenças entre as espécies de Tradução.

O capítulo 3 apresenta a definição da Linguística e sobre o que é a língua ou linguagem. Neste capítulo ainda será possível entender como surgiu o conceito da Sociolinguística Variacionista e quais fatores são determinantes para uma variação linguística.

O capítulo 4 apresenta um breve resumo da primeira temporada da Série "Sintonia" e de seus personagens principais e a metodologia usada nesta pesquisa.

O capítulo 5 apresenta a analise dos dados retirados da série "Sintonia" por meio de transcrições das cenas e uma reflexão sobre o uso de algumas expressões e gírias falada pelos personagens da série.

O capítulo 6 apresenta a considerações finais desta monografia. 


\section{A HITÓRIA DA TRADUÇÃO}

A razão para existir uma variedade de línguas, segundo os historiadores, encontra-se na explicação conforme o Antigo Testamento na passagem da Torre de Babel. A qual foi construída na Babilônia pelos descendentes de Noé com o intuito de colocar limites nas ambições dos homens, assim Deus poderia castigá-los cofundindo as línguas para que não pudessem mais se comunicar. De acordo com BALLARD (1987apud MARTINS, 1999):

\footnotetext{
A tradução não consegue escapar à maldição de Babel; se a tradução é uma inspiração, é o Criador que novamente se exprime em outra língua.
}

Ao longo da história da humanidade, os tradutores foram de suma importância para o desenvolvimento das civilizações. A Tradução sempre esteve presente entre as atividades comerciais e políticas entre os povos de línguas diferentes, além de ajudar a enriquecer as culturas e a integração entre os povos envolvidos.

Estima-se que a Tradução começou na Grécia Antiga, onde os embaixadores eram enviados em missões especiais para diferentes regiões com a finalidade de entregar mensagens, de trocar oferendas e o principal de sustentar o ponto de vista do seu governante. Contudo, para que fosse possível esse contato foi necessário o uso de tradutores, da língua escrita, e intérpretes, da língua oral.

Todavia, foi entre os romanos que surgiram as primeiras teorias sobre a Tradução com Cícero e São Jerônimo que traduziam do grego. Passaram a refletir sobre as dificuldades em como iriam transportar a mensagem de uma determinada língua para que pudessem compreendê-la em outra língua. Cícero defendia a ideia de que:

\footnotetext{
Entretanto, como se cometia um grande erro a respeito de o que era o verdadeiro gênero ático, julguei que realizava um trabalho útil àqueles que amam estes estudos, mas que me é desnecessário. Traduzi para o latim os dois discursos mais célebres dos dois áticos mais eloquentes, Ésquino e Demóstenes, discursos contrários entre si; eu os traduzi para o latim, não como tradutor, mas como orador. Os argumentos permanecem os mesmos, bem como sua forma e figuras de linguagem; as palavras estão conformes ao uso de nossa língua. Não julguei necessário traduzir palavra por palavra; o que mantive foram o tom e o valor das expressões em seu conjunto. Acreditei que não devia entregar ao leitor peça por peça, mas, por assim dizer, seu peso total. (CICÉRON, 1921, p. 111).
} 
Cícero ao dizer essas palavras abriu o caminho para as Teorias da Tradução, essa ideia que mais tarde gerou conflitos em como se devia traduzir. Trazendo a percepção da diferença entre a Tradução palavra por palavra e Tradução mais livre a qual veremos mais tarde neste trabalho na sessão 2.2.1.

Com o declínio do Império Romano o Cristianismo passa a ser triunfante querendo impor uma nova cultura. A Tradução passou a ser vista sobre a ótica da religião, devido a Reforma Protestante que estava em ascensão. As traduções de textos sagrados de São Jerônimo passaram a ganhar êxito e reconhecimento. Ressaltando a noção do original e da fidelidade do original em relação às Escrituras Sagradas. Ele apresenta a existência de duas maneiras de traduzir ao dizer que:

Sim, quanto a mim, não somente confesso, mas também o digo com convicção: quando traduzo os gregos - exceto nas Santas Escrituras, onde a ordem das palavras também é um mistério - o que expresso não é uma palavra por outra, mas uma ideia por outra. (JÉRÔME, 1953, p. 59).

Partindo deste princípio de fidelidade ao original das Escrituras Sagradas, pois naquela época não era bem visto mexer no sentido das palavras de Deus. Desse modo, tanto Cícero quanto São Jerônimo começaram a escrever sobre a Tradução, abrindo caminhos para as teorias que surgiriam em como se deveria traduzir.

A fidelidade ao original é algo discutido até o presente dia, muitos tradutores insistem em se manter fiéis a intenção do autor que é diferente de ser fiel ao texto, e outros, que o tradutor possui a liberdade de ser um coautor e traduzir da maneira que interpretou a obra, dando a sua voz. Conforme afirmou Dryden (1956, p. 182):

\footnotetext{
O tradutor (se é que já não perdeu esse nome) assume a liberdade, não somente de variar as palavras e o sentido, mas de abandoná-las quando achar oportuno, retirando somente a ideia geral do original, atuando de maneira livre, a seu bel-prazer.
}

Sabe-se que a Tradução não tem por intenção a substituição da obra original, pelo contrário o papel do tradutor ao traduzir uma obra é de proporcionar ao leitor, sem o conhecimento de uma língua estrangeira, que tenha acesso a esses conteúdos. Os grandes teóricos partiam do princípio que a Tradução não tinha como manter a fidelidade do original. Com isso surgiu o conceito de Les Belles Infidèles 
[As belas infiéis] por MOUNIN, 1975, ou seja, que a Tradução não podia ser bela sem ser fiel.

Em suma, a questão da fidelidade com as Escrituras Sagradas continuaram pertinentes durante a Reforma Protestante. Em contradição com a Igreja Católica, Martim Lutero decide traduzir a Bíblia para o alemão com o intuito de levar o texto bíblico a toda população que não sabia ler em latim sem se preocupar se a tradução estava se mantendo fiel. Segundo Lutero:

\begin{abstract}
Por outro lado, podeis dizer que traduzi o Novo Testamento o melhor que pude e conscientemente; ninguém tem obrigação de o ler e deixei todos com total liberdade, tendo somente realizado um serviço àqueles que não conseguem fazê-lo melhor. Não proibi a ninguém de fazê-lo melhor. Quem não o quiser ler, que o deixe de lado. Não peço a ninguém para o ler. É o meu Testamento e a minha tradução, e quero que assim o seja. Se cometi algum erro (do que não tenho consciência e, obviamente, não queria ter traduzido nem uma palavra arbitrariamente), não quero que sobre isso decidam os papistas. Possuem as orelhas grandes demais e seus zurros são pouco para julgar minha tradução. Bem sei quanta arte, esforço, razão e entendimento exige uma boa tradução; e eles sabem menos do que o animal do moleiro, pois não o tentaram. [...] Impus-me, ao traduzir, produzir um alemão limpo e puro. [...] Porque não se deve perguntar às palavras do latim como se deve falar em alemão. (1530 apud VEGA, 1994).
\end{abstract}

Assim, durante um determinado período histórico sempre houve uma língua em destaque: a língua franca. Denominada assim, por ser a língua responsável pelas relações de comunicação entre grupos linguisticamente distintos para o desenvolvimento do comércio internacional. Segundo essa definição:

\footnotetext{
Define língua franca, como: um sistema linguístico adicional que serve como um meio de comunicação entre falantes de diferentes línguas maternas, ou uma língua com a qual membros de diferentes comunidades de fala podem se comunicar entre si, mas que não é língua materna de nenhum deles uma língua que não possui falantes nativos. (SEIDLHOFER, 2001, p. 146).
}

Durante o Império Romano a língua franca usada para a comunicação com o oriente foi o grego, e para o ocidente o latim. O latim foi à língua franca das ciências e das artes ate o século XVI. A partir do século seguinte o francês assumiu esse posto por causa da diplomacia que é usado até hoje por muitas instituições internacionais. Já no século XIX até o XX o alemão foi à língua franca em grande parte da Europa devido aos grandes negócios comerciais. Somente na segunda metade do XX, após a II Guerra Mundial que o inglês assumiu esse posto tanto no comércio quanto na diplomacia. 
Com o intuito de impedir que os crimes contra a humanidade pudessem voltar acontecer que foi fundada em 1945 a Organização das Nações Unidas (ONU), no ano que encerrou a II Guerra. A ONU conta com cinco idiomas oficiais além do inglês: o alemão, o francês, o espanhol, o russo, o árabe e o chinês.

Em razão das atividades dos grandes organismos internacionais que a Tradução se tornou de suma importância, posto que, assim, começariam a recorrer do uso de tradutores e intérpretes. Oustinoff (2007) afirmou que:

A tradução é mais que uma operação lingüística simples: as línguas são inseparáveis da diversidade cultural, esta diversidade vital que a ONU, por meio da Unesco, pretende defender, a fim de evitar a proliferação de conflitos devidos ao choque cultural no século XXI.

\subsection{O que é Tradução}

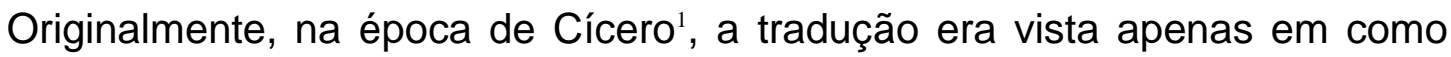
transmitir a ideia de uma língua para outra, visto que o conceito do verbo traduzir, (do latim traducere), segundo o dicionário da língua portuguesa, significa conduzir ou fazer passar de um lado para o outro. (CAMPOS, 1986, p. 7). Segundo John Catford, "a tradução é a substituição de material lexical de uma língua (língua-fonte LF) por material textual equivalente em outra (língua-meta LM)." (1980 apud GEIR, 1987).

A língua em que o texto foi originalmente escrito é chamada de língua-fonte (LF), língua de origem (LO) ou língua de partida (LP). Já a língua pra qual o texto será traduzido é chamado de língua-alvo (LA), língua-meta (LM) ou língua de chegada (LC). Este conceito de tradução foi adotado por muitos linguísticos, mas para Nida (1993), consistia em:

A tradução consiste em produzir na língua de chegada o equivalente natural mais próximo da mensagem da língua de partida, em primeiro lugar no que diz respeito à significação e em seguida no que diz respeito ao estilo.

O tradutor fica encarregado de transmitir o que é falado da língua-fonte para a língua-alvo, se atentando aos conjuntos de signos linguísticos presentes em cada

\footnotetext{
${ }^{1}$ Cícero, no período 46 a. C., entre a Roma cristã e pagã, escreveu o que foi considerado o primeiro texto teórico sobre a Tradução: em como se deveria traduzir literalmente ou livremente.
} 
língua, ou numa mesma língua, como o léxico, o vocabulário, a sintaxe e a cultura. Paulo Rónai acreditava que:

Conduzir uma obra estrangeira para outro ambiente linguístico significa querer adaptá-la ao máximo aos costumes do novo meio, retirar-lhe as características exóticas, fazer esquecer que reflete uma realidade longínqua, essencialmente diversa. Conduzir o leitor para o país da obra que lê significa, ao contrário, manter cuidadosamente o que essa tem de estranho, de genuíno, e acentuar a cada instante a sua origem alienígena. (RÓNAI, 1981, p.20).

Todavia, Catford (1980, p. 53) acreditava no conceito de substituição de significados entre as línguas, e não de uma mera transferência lexical. Eis as suas palavras:

[...] Em "tradução" há substituição de significados da LF [Língua-Fonte] por significados da LM [Língua-Meta]: não transferência de significados da LF para a LM. Na transferência há uma implantação de significados da LF no texto da LM.

De acordo com Britto (2012), a Tradução é fundamental para que se possa manter o contato entre línguas e culturas distintas. É através da tradução que se pode ler um manual, um livro, assistir a um filme, ler bulas de remédio, realizar compras em sites estrangeiros e, até mesmo, ler textos sagrados, ou seja, devido à Tradução, o público-leitor obteve um amplo acesso a produtos estrangeiros.

Considerando o amplo avanço da globalização a tradução passou a ser necessária para a comunicação humana. Ademais, "sem a tradução, o mundo de hoje, com o rápido intercâmbio de informações, seria impensável" (Snell-Hornby, 1988).

Traduzir é uma arte, e não algo mecânico, visto que as palavras isoladas possuem sentidos diferentes de quando estão num contexto. É requerido que o tradutor possua algumas habilidades: ser capaz de entender a mensagem do original, dominar a língua de chegada, ter disciplina e dominar algumas ferramentas de informática que o auxiliarão na tradução: computador, Excel, Word, WordFast, Subtitle Workshop, Skype, e e-mail e dentre outras ferramentas.

Para aqueles que gostariam de ingressar no mundo da tradução a ética é fundamental nesse meio. O comprometimento maior do tradutor é com o seu texto e seu autor, se manter em sigilo sobre as informações contidas no texto, se atentar ao 
cumprimento dos prazos estabelecidos pelo cliente e respeitar os colegas de profissão.

Para Rónai (1981), o tradutor passa por um caminho ladeado de armadilhas. O trabalho do tradutor requer um amplo conhecimento linguístico e cultural das línguas envolvidas, para que o texto seja de fácil compreensão do público-leitor. Já para Bruni (1440 apud VEGA 1994) acreditava-se que:

Por fim, há ainda alguns vícios do tradutor: interpretar mal algo que precisa traduzir, ou reproduzi-lo mal, ou verter algo que o autor original tenha dito de forma justa e harmônica, transformando-o em algo pouco fluido, inarmônico e desordenado.

As estratégias em buscar os recursos externos e internos também ajudam o tradutor a coletar informações que o auxiliarão quando estiver traduzindo. Podendo ser consultados textos paralelos, dicionários e glossários, internet, algum especialista do assunto e a memória de curto e longo prazo, onde se armazena o registro de informações do ser humano. Uma estratégia defendida por Alves (2000) ao dizer que:

\begin{abstract}
Por meio da memória e da produção de inferências, podemos estabelecer mecanismos de apoio interno a fim de processarmos informações de forma mais eficiente. Sabemos que a tradução é uma tarefa que decorre principalmente do bom gerenciamento de informações, inicialmente compreendidas e posteriormente reproduzidas, usando-se para tanto um mecanismo de transferência linguística. Portanto, um apoio interno bem estruturado é um pré-requisito muito importante dentre as habilidades esperadas de um bom tradutor.
\end{abstract}

Dessa forma, a intenção desta pesquisa é analisar a parte linguística e a questão social e cultural da Série "Sintonia", através da Tradução Intralingual e a Sociolinguística Variacionista, por meio das transcrições do áudio original e das falas dos personagens. Contudo, será necessário entender o que é a Tradução Intralingual e como ela se correlaciona com a Sociolinguística Variacionista, visto que possuem um estreito relacionamento já que ambas estudam a língua; no entanto, com aspectos diferentes.

Em suma, além da análise linguística variacionista, a importância desta monografia é de ressaltar e mostrar as variações linguísticas que estão presentes numa mesma língua. Apresentando essas diferenças na sessão 3.2.1 e explicando que podem ocorrer devido às questões geográficas, de gênero, de idade, de cultura, 
do social e da falta de letramento, pois esses são alguns dos fatores que compõem a variação linguística.

\subsection{A Tradução Intralingual}

Com essa variação linguística, a Tradução sofre um grande impacto, principalmente para o Tradutor que precisará traduzir um texto quando a língua de partida é a mesma de chegada, ou seja, traduzir para o mesmo idioma. Todavia, essa tradução interna requer muito conhecimento do mesmo sobre a cultura dessa língua.

No caso desta pesquisa, o intuito será de apresentar como seria feita essa espécie de Tradução entre estados brasileiros que apresentam essas variações linguísticas diferentes.

Entretanto, antes da análise variacionista, é necessário entender as diferenças existentes dentro da Tradução, estas podendo ser: Interlingual, Intralingal e Intersemiótica. Esses três tipos de espécies de tradução são explicados por Jakobson (1971, p. 64-65):

[...] Distinguimos três maneiras de interpretar um signo verbal: ele pode ser traduzido em outros signos da mesma língua, em outra língua, ou em outro sistema de símbolos não verbais. 1) A tradução intralingual ou reformulação ("rewording") consiste na interpretação dos signos verbais por meio de outros signos da mesma língua. 2) A tradução interlingual ou tradução propriamente dita consiste na interpretação dos signos verbais por meio de alguma outra língua. 3) A tradução intersemiótica ou transmutação consiste na interpretação dos signos verbais por meio de sistemas de signos não verbais.

É valido ressaltar que não há uma tradução perfeita, mesmo que ela consiste em traduzir signos verbais da mesma língua, de línguas diferentes ou de signos não verbais. Desse modo, é notório dizer que não há uma comunicação perfeita, devido à limitação humana. Todavia, o importante é que seja satisfatória alcançando os seus objetivos de comunicação entre os indivíduos.

Não importa qual seja a espécie da Tradução, toda comunicação verbal, ela sendo entre diferentes línguas ou na mesma língua, exige algum tipo de Tradução. Para Murata (1996, p.69), "tudo o que se diz é uma tradução do que já se disse". Já para Octavio Paz (1971 apud ARROJO, 1986, p.11), "a própria língua, em sua essência, já é uma tradução: em primeiro lugar, do mundo não verbal e, em 
segundo, porque todo signo e toda frase é uma tradução de outro signo e de outra frase".

Entretanto, quem melhor esclarece essa questão da correlação da Tradução com a Linguística é Jakobson (1971, p. 64), ao afirmar que:

[...] o significado de um signo linguístico não é mais que sua tradução por um outro signo que lhe pode ser substituído, especialmente um signo 'no qual ele se ache desenvolvido de modo mais completo', como insistentemente afirmou Peirce, o mais profundo investigador da essência dos signos.

Nas palavras de Mounin (ibid, p. 35-36), onde ele cita e ressalta uma crítica de Saussure, não se pode de forma alguma por em dúvida a natureza universal dos conceitos independente da experiência universal de cada indivíduo. Já que a língua não é uma mera nomenclatura, um repertório, algo ensaiado, mas sim, algo de acordo com a experiência de cada indivíduo.

Sendo assim, podemos dizer que cada língua contém seu sistema sui generis; segundo o dicionário significa o seu código próprio, suas formas e regras. Contudo, possuem ao mesmo tempo um sistema de comunicação, o que possibilita ser possível a tradução, visto que a comunicação é essencial para a vida humana.

Toda língua é uma estrutura formal - um código - que consiste em elementos que podem combinar-se para veicular 'sentido' semântico e, ao mesmo tempo, um sistema de comunicação que emprega as formas do código para referir-se a entidades (do mundo real ou imaginário) e cria sinais que possuem 'valor' comunicativo. (BELL, 1991, 6-7).

Mesmo que não haja uma correspondência exata em significados entre as línguas, pode haver na correspondência ou na significação, do contrário não seria possível à Tradução. No entanto, é critério do tradutor escolher no que focar, se tentará manter o sentido do original ou optará apenas por exercer a comunicação para o leitor. Bell (1991) nos esclarece da seguinte forma:

O tradutor tem opção, então, de focalizar quer as equivalências formais, que 'preservam' o sentido semântico do texto original, (...) quer as equivalências funcionais, que 'preservam' o valor comunicativo do texto (...) (p.7). 


\subsubsection{Tradução Literal VS Livre}

Alguns tradutores definem a Tradução apenas como uma arte exclusiva, imponderando a arte literária e a artística, enquanto há outros que a definem como uma operação linguística.

De acordo com Mounin (ibid, p.24), essa divergência entre os tradutores ocorre devido à existência de dois tipos de Tradução: a literal e a livre. A Tradução literal normalmente é defendida por tradutores que a define como uma operação essencialmente linguística, ou seja, mais direta, objetiva e fiel ao original. Já a Tradução livre é defendida por não linguísticas, tradutores poetas, que veem a Tradução apenas como uma arte, subjetiva, parcial e infiel ao original.

Peter Newmark (1988, p. 69), é um dos tradutores que defendem o conceito da Tradução Literal, ou seja, se manter fiel ao original. Ele afirma que "a Tradução literal é correta e não deve ser evitada, uma vez que assegure a equivalência referencial e pragmática em relação ao original".

Outro tradutor que defendia esse conceito era Bruni (1440 apud VEGA 1994) ao dizer que:

[...] O bom tradutor de um texto se dedicará com toda sua mente, seu espírito e sua vontade ao autor original do texto, e de certa forma traduzirá a forma da frase, sua construção, seu estilo e seu colorido, e meditará sobre a melhor maneira de expressar todos estes traços. Disto resulta um efeito admirável. [...] O melhor método para se traduzir é o seguinte: conservar da melhor maneira a estrutura da frase original, sem que as palavras traiam o sentido nem o esplendor nem a beleza das próprias palavras.

É Britto (2012, p. 37), quem esclarece sobre a divergência da Tradução Livre: "A fidelidade absoluta é uma meta perfeitamente válida, ainda que saibamos muito bem que, como todos os absolutos, ela jamais pode ser atingida".

Este conceito de Tradução Livre era defendido por Bacon (1262 apud VEGA 1994):

[...] é impossível preservar o caráter distintivo de uma língua em outra, já que precisamente as expressões idiomáticas de uma mesma língua tendem a diferir entre seus falantes [...] Portanto, o que se diz muito bem em uma língua não se pode traduzir para outra da mesma maneira.

Vale ressaltar que, dependendo do público-alvo e do tipo de texto, pode ser que a Tradução seja como uma arte literária (mais subjetiva) - de acordo com a 
Tradução livre - ou podendo ser voltada para os aspectos referenciais (um texto mais objetivo) de acordo com a Tradução literal. Nesse aspecto, de qual tipo de Tradução seguir (a literal ou livre) que originou a polêmica e o conceito de "As belas e Infiéis" por Mounin em 1975: de ser ou não ser fiel à intenção do original.

\subsubsection{O papel do Tradutor}

Como foi visto na sessão 2.1, a tradução teve e ainda tem um papel importante na história da humanidade. Graças à tradução que muitos passaram a ter acesso a outras culturas por meio de texto estrangeiro, um filme, uma série, uma música, ou até mesmo os desenhos todos traduzidos para qualquer idioma. De fato, com a globalização, a Tradução passou a ser essencial na sociedade.

Compete-se ao tradutor o papel de coletar informações sobre o assunto requerido tanto na língua-fonte quanto na língua-meta. Os dados coletados pelo tradutor são extremamente importantes para o êxito final da tradução.

Vale ressaltar que durante o processo tradutório é o corpus coletado pelo tradutor que o guiará nas escolhas a serem feitas. A título de exemplo, se o texto for jurídico o tradutor, primeiramente coletará um corpus embasado sobre tudo que compete à jurisdição, tudo antes de começar a traduzir, assim, quando surgir quaisquer dúvidas sobre termos ou algo semelhante o tradutor terá em seu favor todas as informações que o auxiliarão na tradução.

Um corpus para o tradutor são as informações coletadas sobre o assunto requerido. Essas informações podem conter quais termos técnicos precisam ser usados, ou quais fraseologias a serem usadas naquele assunto em questão. Pesquisas - com os links salvos - em sites confiáveis, principalmente de organizações governamentais, para saber como um termo específico da língua-fonte é usado na língua-meta e se há ou não equivalências. Ademais, é o corpus que guia e auxilia o tradutor durante o processo tradutório. Krieger (2004) esclarece termo e fraseologia na seguinte maneira:

Termo: “(...) o termo é uma unidade lingüístico-comunicativa, resultado de determinada conceitualização por parte de um falante e, simultaneamente, oferta de interpretação para seus eventuais destinatários".

Fraseologia: "A idéia de fraseologia está associada a uma estruturação lingüística estereotipada que leva a uma interpretação semântica 
independente dos sentidos estritos dos constituintes da estrutura. É nessa perspectiva que se enquadram expressões idiomáticas, frases feitas e provérbios utilizados nas diferentes línguas. Além disso, locuções nominais e verbais são também compreendidas como fraseologias, bem como outras estruturas típicas de determinado tipo de comunicação, como é caso das fórmulas protocolares de abertura e fechamento em correspondências formais."

No caso de uma Tradução Interlingual, o papel do tradutor será de coletar informações para o corpus entre a língua-fonte e a língua-meta. Já no caso de uma Tradução Intralingual, que é foco deste trabalho, o tradutor terá como o papel de coletar as informações sobre as variáveis daquela língua-fonte em questão, a qual será a mesma da língua-meta. Seu papel será de pesquisar sobre as variedades daquela língua e detalhar as informações no corpus. A título de exemplo, ao traduzir um texto que foi escrito por gaúchos, contendo expressões e gírias locais, mas será lançado na Bahia, o tradutor neste caso ao coletar as informações sobre as possíveis variações ele ainda terá que adequar o texto com o dialeto gaúcho para o dialeto baiano, visto que são dialetos diferentes podendo assim a mensagem não ser compreendida. 


\section{LINGUÍSTICA}

Podemos dizer que através da religiosidade que a humanidade passou a estudar mais sobre a língua. Devido a uma diversidade entre as línguas, foram através dos religiosos com suas vivências e conhecimentos entre um lugar e outro. No entanto, o latim ainda era mantido como a língua universal perante a religião.

Todavia, somente no século XIX com o afloramento dos estudos sobre as línguas em comparação de como ela era falada, assim, surgia à gramática comparada da Linguística histórica da língua.

Descobriram que havia semelhanças entre as línguas e que elas se transformaram ao longo do tempo. Que o latim deu origem a outras línguas como: Espanhol, Português, Francês e, outras diversas línguas.

Toda língua possui uma infinita combinações de sons podendo ser representados através da escrita. Cabe ao linguista descrever e determinar esses tipos de sons.

Compete-se a Linguística uma investigação da linguagem verbal humana, estudar os conjuntos de signos numa comunicação. A linguística não se baseia na gramática tradicional, visto que ela investiga e procura entender e escrever a linguagem em seu uso através de seus falantes. Para o linguista a diferença de sotaques entre regiões não pode ser considerado como errado, para ele é válido essa diferença e isso se torna seu objeto de estudo.

A metodologia de analise linguística primeiro analisará a fala e depois a escrita. Cabe o linguista analisar a língua falada investigando a distância entre a fala e a escrita, devido a inúmeros fatores. Esse é um dos fatores mais complicados dentro da Linguística, entender que a língua falada tem a sua independência da língua escrita. É dever de o linguista gerar os dados entre os falantes para assim obter resultados significantes sobre a linguagem.

Há dois campos de estudo: a Linguística Geral e a Descritiva. A Linguística geral é o modelo que dá fundamento a analise das línguas. Já a Linguística descritiva é os dados que confirmam os fundamentos das línguas. Não pode haver a linguística geral sem embasamento na linguística descritiva. Lyons esclarece da seguinte forma: 
Cada uma depende explicita ou implicitamente da outra: a linguística geral fornece conceitos e categorias em termos dos quais as línguas serão analisadas; a linguística descritiva, por sua vez, fornece dados que confirmam ou refutam as proporções e teorias colocadas pela linguística geral. (2009, p. 34).

A gramática tradicional coloca a língua escrita como modelo padrão para a linguística não reconhecendo as diferenças entre a língua escrita e a falada. A gramática teve desde a sua origem como o objetivo de prescrever e normatizar uma língua, assim como foi com a língua sânscrita a primeira língua a ter uma prescrição Linguística.

A normatização da língua é justamente para prescrever um modelo padrão de língua falada dentro de uma determinada região, assim, normatizando uma única maneira certa de se usar a língua. As autoridades que determinam o que é correto; no entanto, não são todas classes que se expressam corretamente segundo a norma padrão. As classes altas são instruídas a usarem a norma padrão as inferiores não, mesmo falar correto sendo algo muito valorizado pela sociedade.

Através da Linguística que falsos conceitos ou preconceitos foram desvendados sob o olhar exclusivamente da língua normativa um deles foi que a língua escrita não pode servir de exemplo para a língua falada por serem distintas historicamente já que a língua falada precedeu à escrita. Para Fiorin (2007) "Toda língua natural possui o que é necessário para que haja comunicação entre os indivíduos". Nenhuma língua é superior à outra, o que há é uma diferenciação vocabular, na sintaxe, no léxico.

Com o intuito de descrever a língua que através de um corpus, o qual continha informações sobre a língua, que a Linguística passou analisar frases e expressões de acordo com o seu uso.

A Linguística se fundamenta em dois princípios: o empirismo e a objetividade. Segundo Fiorin (2007), no empirismo a linguística trabalha com dados por meio da observação. A objetiva trabalha livremente, sem falsos conceitos sócios e culturais ela é mais independente.

\subsection{0 que é lingua(gem)}

Ao longo dos séculos através de pesquisas Linguísticas foi capaz de analisar e separar a ciência da norma de uma língua. As mudanças que ocorrem na língua 
foram observadas, historicamente, com uma origem na fala popular, visto que são nas classes inferiores onde mais se havia uma variação linguística por não possuírem conhecimento normativo da língua. Todavia, o que era errado numa época passou a ser considerado o correto na seguinte.

A língua é transformada a todo instante devido ao fato dela ser falada, a qual ocasiona uma variação linguística até mesmo falada por pessoas cultas. Entretanto, a língua prescritiva não admite mais de uma forma correta, não podendo ter escolhas dentro de uma língua a não ser a forma padrão.

A língua é um instrumento de comunicação falado por indivíduos que podem ou não pertencer a uma mesma comunidade de fala. Em uma determinada comunidade linguística - a dos falantes do português, por exemplo - todos os membros conseguem se comunicar e se compreender graças à língua, um sistema abstrato de regras e relações presente em todo o ato da fala (DUBOIS, 2001, p. 378).

De acordo com Leonard Bloomfield:

"Uma comunidade linguística é um grupo de pessoas que age por meio do discurso" (...) "os membros de uma comunida linguística podem falar de um modo tão semelhante que cada qual pode compreender o outro podem se diferenciar a ponto de pessoas de regiões vizinhas chegarem a não se entender umas às outras." (apud CALVET, 2002, p.115).

Já para Willian Labov:

"Não considerava a comunidade linguística como um conjunto de falantes empregando as mesmas formas", mas como "um grupo de falantes que tem em comum um conjunto de atitudes sociais para a língua." (apud CALVET, 2002, p.116).

Saussure (2007) acreditava na linguagem descritiva, ou seja, que a descrição de um fato era o bastante para julga-lo. Já Chomsky (1988) se preocupava mais com a teoria do que com dados. Dessa forma, havia uma teoria explicativa que precedia os dados podendo explica-los. É a competência do falante que organiza os elementos linguísticos numa determinada frase.

Para Chomsky (1988), a linguagem é algo geneticamente passado de um ser para outro e, não algo adquirido durante o processo de aprendizagem de uma criança ela é apenas acionada quando está aprendendo sobre alguma língua. 
Contudo, Costa et al. (2011, p. 16) esclarecem que, para a linguística, a linguagem é "a capacidade que apenas os seres humanos possuem de se comunicar por meio de línguas". Ademais, a linguagem é o meio de comunicação dos indivíduos podendo ser através da linguagem corporal, por sinais, e dentre outras.

Chomsky (1988) distingue a competência de desempenho. Para ele a competência linguística é adquirida conforme a aprendizagem do falante durante a infância. Já o desempenho linguístico seria adquirido com ajuda de fatores externos na vida do falante.

Pode-se dizer que a gramática é gerativa, pois a partir de um determinado número limitado de regras pode ser gerado uma infinidade de outras sentenças. Assim é o falante, ele gera uma infinidade de sentenças novas a partir de uma nova experiência.

A função dos gerativistas é justamente de desfazer essa ligação da gramática universal com as analises das propriedades da língua em seu uso.

Já a proposta da gramática funcional seria de levar em consideração o uso das expressões linguísticas levando em consideração todo o contexto da comunicação. No funcionalismo a língua é um instrumento de interação social usado para estabelecer relações comunicativas entre os indivíduos.

Essas duas possibilidades explicativas não são as únicas, porém são as que possuem abordagens linguísticas que ajudam a compreender melhor as diferenças no complexo fenômeno da linguagem que não se limita na gramaticidade da língua, mas que também nas abordagens do contexto histórico, sócio e cultural dela.

Segundo Mattoso (1979), a língua aparece na comunicação por meio da fala por onde os falantes se comunicam uns com os outros, e por meio desses sons vocais que é transmitido ideias, impressões e sentimentos. Mas não é tal comunicação que constitui a língua. Ela se concretiza através de um determinado ambiente, em meio de uma situação definida, concreta, diante de dados individuais e, assim a situação estabelecida colabora para uma comunicação.

Dados extralinguísticos podem colaborar para a transformação na língua, em circunstâncias reais em que o indivíduo se encontra, depois, juntando com os gestos durante a fala, toda uma linguagem de sinais. Ela oferece uma norma padrão como estrutura, ela é assim antes de tudo, no seu plano, uma representação do mundo cultural em que o falante se encontra e, como ele representa esse mundo. 
Mattoso (1979, p.66), diz que a língua está sempre em constante transformação e porquanto, tem uma história que, institui-se de uma distinção entre o estudo e a descrição de uma língua ou de uma parte dela ao longo de sua história, ou seja, a diacronia, e o estudo sincrônico, que é o estágio de uma língua considerado num momento dado, independente de sua evolução histórica no seu funcionamento contemporâneo. De acordo com Lyons:

Uma descrição diacrônica percorre o desenvolvimento histórico da mesma e registra as mudanças que nela ocorreram entre pontos sucessivos no tempo. A descrição sincrônica é não-histórica: apresenta uma imagem da língua tal qual ela se encontra em determinado pouco tempo. (LYONS, 2009, p.35).

Podem acontecer nas transformações linguísticas três acometimentos decisivos principais. Primeiro é associação entre a cultura e a língua, segundo, um impulso para a mudança é a natureza estilística e terceiro, ela é um sistema, uma estrutura em que os elementos estão ligados entre si por associações e contrastes, mas não é um sistema nem completo nem fechado. Como dizia Saussure (2007), estão em equilíbrio instável, com uma série de pontos fracos, e esses pontos fracos são sempre suscetíveis de sofrer modificações.

Portanto, as alterações de caráter sociocultural comprometem a língua, e essas fatos, por sua vez, considerados sob diversos ângulos, marcam etapas dos estudos linguísticos. Os diversos modos de analisar e abordar os fenômenos da linguagem estabelece a história da linguística e descrevem o seu trajeto ao longo do tempo.

Segundo Fiorin (2007), "A língua é considerada uma estrutura constituída por uma rede de elementos, em que cada elemento tem um valor funcional determinado". Ademais, a língua é um conjunto de signos necessários para que haja uma comunicação, se adaptando e flexibilizando as diferenças permitindo que consiga expressar quaisquer significados até mesmo sentimentos e emoções.

Outra definição de língua é dada por Saussure, que define a língua como "um produto social da faculdade da linguagem e um conjunto de convenções necessárias, adotadas pelo corpo social para permitir o exercício dessa faculdade nos indivíduos". (SAUSSURE, 2007, p. 17). Ainda de acordo com Saussure (2007), a língua é um objeto de natureza homogênea e concreta. Diferente de Labov (2008) 
que a trata a língua como um sistema heterogêneo, o qual será visto na próxima sessão 3.2.

Já para Preti (1997, p. 12), a língua, "funciona como um elemento de interação entre o indivíduo e a sociedade em que ele atua" e sua importância constitui-se tanto na sua forma oral, ou seja, na fala, quanto no seu código substitutivo escrito (PRETI, 1997).

Um dos desafios é a oposição entre língua falada e língua escrita, pois a primeira é mais passível de mudanças e a segunda, teoricamente, é mais conservadora (PAGANINE; FONSECA, 2015).

Lyons (1987, p. 18), esclarece da seguinte maneira a relação entre língua e fala:

[...] há uma estreita ligação entre língua e fala. Logicamente, esta pressupõe aquela: não se pode falar sem usar a língua (isto é, sem falar uma determinada língua), mas é possível usar a língua sem falar. No entanto, dado que a língua é logicamente independente da fala, há boas razões para se dizer que, nas línguas naturais tais como as conhecemos, a fala é historicamente, e talvez biologicamente, anterior à escrita. E esta é a posição da maior parte dos linguistas.

Desta forma, é possível afirmar que pode significar um desafio para 0 sociolinguista, já que este terá que representar na língua escrita - que costuma ser mais formal - uma mensagem originalmente falada, que costuma ser mais coloquial. (OLIVEIRA, 2018). Ainda segundo este autor:

$\mathrm{Na}$ fala, o falante pode usar alguns recursos, como gestos e expressões faciais, evitando que haja qualquer perda de compreensão por parte do ouvinte, que está presente no ato da fala. Na língua escrita, por outro lado, não é possível utilizar esses recursos. (OLIVEIRA, 2018).

Dessa forma, a variação linguística se mostra muito mais presente na língua falada do que na escrita, embora ainda esteja bastante presente nesta última. Como veremos adiante no capítulo 5.

\subsubsection{Língua e Cultura}

Conforme foi apresentado na sessão anterior 3.1, a língua é um fator social e, por conta disso é passiva de variações, visto que é falada por indivíduos socialmente 
distintos. Assim, "A língua é uma ferramenta de comunicação que capacita seres humanos a expressarem seus pensamentos e sentimentos". (JUNIOR, 2020, p. 42).

Através da língua que há a comunicação entre indivíduos mesmo que sejam de classes sociais iguais ou regiões, é por conta da língua que os povos se comunicam.

Para Paes (1990, p. 33), "cada língua constitui uma visão de mundo diferenciada e única a que só se pode ter acesso por via dessa mesma língua e de nenhuma outra." Essa visão extremista da língua é defendida pela Hipótese de Sapir-Whorf:

\footnotetext{
"A língua determina a maneira como as pessoas recebem e organizam o mundo. Esta visão (de 'determinismo linguístico') foi exposta primeiramente pelo etnólogo alemão Wilhelm Von Humboldt (1767-1835); no presente século, veio a ser conhecida como HIPÓTESE DE SAPIR-WHORF." (CRYSTAL, 1988, p.226).
}

Contudo, ao falar de língua é importante ressaltar a cultura, visto que esta também não deixa de ser um fator social. Segundo Eagleton (2005 apud JUNIOR, 2020, p.43), não há uma definição exata para cultura; todavia, será utilizado o conceito de que cultura nada mais é que um conjunto de costumes, de crenças e valores transpassados de gerações para um determinado povo ou individuo.

A título de exemplo, em dias chuvosos com raios e trovões, é costume dos mais velhos cobrir todos os espelhos da casa, não usar talheres de prata, evitar ficar na janela e de usar qualquer aparelho eletrônico, pela crença que pode atrair raios para dentro da casa. É a cultura passada de geração a geração daquele individuo, uma crença que ensinam aos mais novos e, assim este costume perpetuará naquela família.

Cabe ressaltar, que a cultura ela caracteriza o indivíduo, destaca-o perante a sociedade, posto que sejam características únicas que podem influenciar outros indivíduos a enxergarem o mundo de uma maneira diferenciada da dele. Desse modo, o individuo pode tanto influenciar outro indivíduo quanto o meio pode influenciá-lo também. Por exemplo, viajar para uma região cujo há um sotaque totalmente diferente do seu, ao voltar de viajem, percebe-se que adotou aquele sotaque e que está se comunicando como aquele povo, algo que flui naturalmente.

A partir disso, é notório que o ser humano não conhece todos os aspectos da língua que ele fala, por ela ser dotada de variações e muitas das vezes pertencendo 
a grupos específicos de uma determinada cultura que podem possuir a sua linguagem própria. (Junior, 2020). Como é o caso das gírias a ser visto mais aprofundado na sessão 3.2.2.

È importante ressaltar a ligação entre língua e cultura em uma determinada sociedade. A língua exprime nossos sentimentos, sensações, influência nosso comportamento e define as reações de um determinado grupo social. Já a cultura é expressa por meio da linguagem, ela é concretizada através do uso cotidiano de seus indivíduos que dão significados e sentidos.

\subsection{A Sociolinguística Variacionista}

A relação entre língua e sociedade é inegável dentro dos estudos da Sociolinguística. Uma área que estuda a língua falada, a do cotidiano, a qual leva em consideração a heterogeneidade dentro da língua devido às variações que a compõe em relação às questões culturais, sociais, econômicas e regionais no processo da comunicação.

Para a Sociolinguística, a língua é dotada de "heterogeneidade sistemática", fato que permite a identificação e demarcação de diferenças sociais na comunidade. Constituindo-se como parte da competência linguística dos indivíduos, o domínio de estruturas heterogêneas (WEINREICH; LABOV; HERZOG, 2006, p.101).

Michail Bakhtin (1990) defendia a ideia de que a língua possuía um caráter social e que se realizava através de atos enunciativos em determinada circunstância de interação verbal.

Já para Cezario e Votre (2008, p. 141), "a sociolinguística é uma área que estuda a língua em seu uso real, levando em consideração as relações entre a estrutura linguística e os aspectos sociais e culturais da produção linguística". Desse modo, para os sociolinguistas, a língua é um instrumento social e deve ser estudada juntamente em relação com o contexto situacional dos falantes da língua, ou seja, no ato da fala. Ademais, é preciso levar em consideração a cultura e a história de uma língua ao fazer uma análise linguística (CEZARIO; VOTRE, 2008).

Contudo, Willian Labov (2008) foi quem considerou a existência de somente um tipo de linguística, a social, e que não havia razões para se destacar o caráter social da língua em relação a essa nova área de estudo. 
Labov (2008) criou um modelo metodológico conhecido como "Sociolinguística Variacionista" ou "Teoria da Variação" - que consiste num estudo da linguagem social através da coexistência de variantes linguísticas e as suas probabilidades de uso na comunicação.

Essa metodologia, no estudo da análise linguística trabalha com uma abordagem baseada em pressupostos do pesquisador, o sociolinguista, ao gerar informações de números e estatísticas dos dados coletados numa comunicação do cotidiano.

É dever de o sociolinguista analisar essas variações por meio de pesquisas de campo ou por entrevistas gravadas com pessoas de regiões ou de classes sociais diferentes. Assim, para que possa ter um objeto de estudo e poder analisar os fatores que desencadeiam tais variações.

Essas diferenças na comunicação ocorrem devido às variedades linguísticas, ou seja, diversas maneiras de se falar a mesma coisa em um mesmo contexto. Com essa metodologia de análise é possível verificar o porquê de essas variações acontecerem, qual contexto que pode ou não favorecê-las. Cabe, assim, ao sociolinguista descobrir esses fatores.

\footnotetext{
Um dos seus objetivos é entender quais os principais fatores que motivam a variação linguística, e qual importância de cada um desses fatores na configuração do quadro que se apresenta variável. O estudo procura verificar o grau de estabilidade de um fenômeno, se está em seu inicio ou se completou uma trajetória que aponta mudança. Em outras palavras, a variação não é vista como um efeito de acaso, mas um fenômeno cultural motivado por fatores linguísticos (também conhecidos como fatores estruturais) e por fatores extralinguísticos de vários tipos. (CEZARIO, 2008, p.141).
}

Esses fatores que desencadeiam a variação linguística podem acontecer devido ao nível de escolaridades dos falantes durante a comunicação, do sexo, da idade, da etnia, do nível socioeconômico, do espaço geográfico e da cultura que está inserida no seu dia-a-dia, conforme será visto na sessão 3.2.1.

Conforme Labov (1978), dois enunciados que se referem à mesma coisa com o mesmo valor de verdade constituem-se como variantes de uma mesma variável. Por exemplo, em um determinado enunciado podem-se ter as variáveis linguísticas com concordância, ou não concordância do verbo com o sujeito, praticadas por diversos falantes na linguagem cotidiana. Outro bom exemplo são as diversas formas lexicais que as palavras assumem em certas culturas ou tradições, como o 
caso das variações linguísticas conhecidas como gírias que, de acordo com os fatores sociais que incidem sobre os grupos de falantes que as praticam, possuem significados diferentes para palavras ou termos usados na linguagem formal e padronizada.

De acordo com a Língua Portuguesa, na norma culta, em relação a esses exemplos citados a cima, mesmo sendo praticados no cotidiano por falantes da língua portuguesa tanto a não concordância do verbo com o sujeito quanto à utilização de gírias na linguagem oral não são considerados gramaticalmente adequados para o uso.

As variáveis linguísticas classificam-se em dependentes e independentes. As primeiras são o próprio fenômeno a ser estudado, como por exemplo, a ocorrência da concordância nominal em determinado enunciado, cujas variáveis seriam o uso ou não da regra de concordância gramatical. Já as independentes dizem respeito aos fatores linguísticos internos (estruturais) e os externos (socioculturais).

\subsubsection{As Variações Linguísticas}

Com a ascensão e a globalização do mundo, as línguas acompanham essa evolução e mudam a cada instante, assim, não há somente uma língua universal, e sim uma variedade de línguas. Para Calvet (2002), "O plurilingüismo faz com que as línguas estejam constantemente em contato".

Sendo assim, por ser um fator social, é natural que as línguas variem dessa maneira satisfazendo as necessidades de seus falantes. (Saussure 2007). Línguas são faladas por pessoas, e cada pessoa possui a sua identidade o que a difere dos demais. Qualquer língua, portanto, está sujeita ao fenômeno da variação.

Varia-se de acordo com sua região geográfica, classe social, sexo e faixa etária. A língua difere da maneira que fala em relação de como se escreve, mesmo que a gramática tradicional não reconheça:

\footnotetext{
A gramática tradicional, ao fundamentar sua análise na língua escrita, difundiu falsos conceitos sobre a natureza da linguagem. Ao não reconhecer a diferença entre língua escrita e língua falada passou a considerar a expressão escrita como modelo de correção para toda e qualquer forma de expressão Lingüística. (FIORIN, 2007, p. 18).
} 
Para Paes (1990), "cada língua constitui uma visão de mundo diferenciada e única a que só se pode ter acesso por via dessa mesma língua e de nenhuma outra". São as variáveis da língua que a constitui, a complementa. A mesma língua pode ser pronunciada de diversas formas diferentes, desde que haja sucesso na comunicação:

Entenderemos aqui por variável o conjunto constituído pelos diferentes modos de realizar a mesma coisa (um fonema, um signo...) e por variante cada uma das formas de realizar a mesma coisa. (CALVET, 2002, p. 90).

Cezario e Votre esclarecem variação da seguinte maneira:

[...] "a variação não e vista como um efeito de acaso, mas como um fenômeno cultural motivado por fatores linguísticos (também conhecidos como fatores estruturais) e por fatores extralinguísticos de vários tipos [...] A variação ilustra o caráter adaptativo da língua como código de comunicação e, portanto, a variação não é assistemática". (2008, p. 141).

Há dois tipos de Variáveis a Linguística e a Social. È correto afirmar, que a variável linguística são as maneiras de dizer o mesmo objeto em maneiras diferentes. Já a variável social é a maneira que essas diferenças linguísticas afetam na função social do indivíduo. Para Cavelt:

Temos pois variável linguística quando duas formas diferentes permitem dizer "a mesma coisa", ou seja, quando dois significantes têm o mesmo significado e quando as diferenças que eles representam têm uma função outra, estilística ou social. (2002, p. 103).

A título de exemplo, a privada, o vaso e ou trono são notoriamente variáveis de um ou mais significantes tendo o mesmo significado. No entanto, o que implica é na função que esses significantes correspondem na comunicação. Os usos dessas palavras no cotidiano diferenciam-se de acordo com a faixa etária de seus usuários: os mais velhos (avós) diriam privada, os adultos (pais) diriam vaso, e os jovens (filhos) diriam trono.

Dessa forma, a faixa etária é um dos fatores determinantes para uma variação social, visto que há diferentes formas do uso de um mesmo significante de acordo com a idade do indivíduo. Cada faixa etária é diferente da outra, com vocabulários próprios como os adolescentes que se destacam inovando e ampliando o 
vocabulário que um adulto não conseguiria entender a mensagem, assim, não haveria uma comunicação por não pertencer àquela comunidade de fala específica.

A segregação social também é um dos fatores que podem ocasionar a variação social devido às classes sociais, fatores socioeconômicos, à segregação imposta pela alta e preconceituosa sociedade devido às diferenças no grau de escolaridade e nas classes sociais aonde surge o preconceito linguístico que retomaremos mais adiante.

Mulheres falam diferentes de homens, são características diferentes por causa do convívio social. As mulheres se destacam por inovar no vocabulário, criam mais e usam mais a forma padrão da língua que os homens. Neste caso, o sexo dos indivíduos pode desencadear uma variação.

A questão da região geográfica associada com a distância entre cidades, até mesmo de um estado ou regiões dentro de um país permitindo assim variações linguísticas ou sociais de acordo com cada região. Assim, por exemplo, a fruta tangerina pode ser dita em diversas maneiras pelas regiões do Brasil: no Sudeste, principalmente no Rio de Janeiro é conhecida como "Tangerina"; em São Paulo, Minas Gerais e Goiás é conhecida por "Mexerica"; no Rio Grande do Sul por "Bergamota"; em Curitiba por "Mimosa"; No Nordeste principalmente Bahia e no Mato Grosso por "Tangerina e Mexerica”; e Mato Grosso do Sul por "Poncã".

É dever de o sociolinguista averiguar tais variações tantas linguísticas quantas sociais, pesquisando relações entre elas, a fim de observar e analisar como tais variações se configuram dentro de uma comunidade de fala. Um dos seus objetivos é entender de que maneira um contexto linguístico e extralinguístico pode interferir uma comunicação ou motivar a uma variação.

Com a variação da língua dentro de um país, o que permite a comunicação sem que nada impeça a mensagem de ser compreendida é a norma culta, assim todos conseguem reconhecer a língua e se comunicar. Desse modo, de acordo com o contexto social da comunicação que surge o preconceito linguístico em relação ao dialeto padrão - o puro, o correto - entre o dialeto não padrão - considerado incorreto:

A variante padrão é ensinada na escola e valorizada pelos membros da sociedade, tanto pelos que a dominam como pelos que gostariam de dominá-la, posto que sabem da sua importância para se adquirir prestígio. (CEZARIO, 2008, p.145). 
Dessa forma a Sociolinguística tem por finalidade criar uma visão que os dialetos considerados não padrão pronunciados geralmente pela classe desfavorecida devida á falta de letramento não sejam rotulados como inferiores ou incorretos, mas sim como uma variação da língua. Para Bortoni-Ricardo:

Quando a língua padrão é associada a classe social, torna-se símbolo de status. As classes sociais que detêm prestígio e poder têm amplo acesso a ela; as classes inferiores na pirâmide social aspiram ao domínio dessa norma padronizada, que vão aprender na escola. (2014, p. 71).

Essa visão menos preconceituosa imposta pelos sociolinguistas permite que professores possam ensinar as diferenças sócias e culturais da língua mesmo que não siga as regras gramaticais a língua é dotada de variações e não pode ser considerada como única.

Dessa forma, Bagno (2007, p. 16-17) esclarece que:

[...] se formos acreditar no mito da língua única, existem milhões de pessoas neste país que não têm acesso a essa língua, que é a norma literária, culta, empregada pelos escritores e jornalistas, pelas instituições oficiais, pelos órgãos do poder - são os sem-língua. É claro que eles também falam português, uma variedade de português não-padrão, com sua gramática particular, que no entanto não é reconhecida como válida, que é desprestigiada, ridicularizada, alvo de chacota e de escárnio por parte dos falantes do português-padrão ou mesmo daqueles que, não falando o português-padrão, o tomam como referência ideal - por isso podemos chamá-los de sem-língua.

De acordo com Oliveira:

O texto literário, como representante da língua em uso e recriador da realidade social, além de ser analisado sob o ponto de vista do preconceito em relação às variedades consideradas "desvios da norma" ou variedades "inferiores", também pode ser compreendido sob o ponto de vista da importância representativa para as comunidades de fala, tanto em relação à variação utilizada pela comunidade, quanto em relação à realidade social, econômica e cultural vivida pelos falantes. (OLIVEIRA, 2018).

Desse modo, qualquer tradutor, principalmente o iniciante, é necessário se atentar a essas variações linguísticas, principalmente, quando é preciso fazer uma tradução interna, ou seja, para a mesma língua de chegada e de partida.

Ademais, tanto o papel do tradutor quanto do sociolinguista tem por finalidade, além de analisar as diferenças linguísticas, mas também de criar um corpus com os dados gerados sobre as tais variações. 


\subsubsection{Dialeto VS Gírias}

Conforme foi visto, a língua é dotada de variações, nesta sessão entenderemos as diferenças entre o dialeto e a gírias que são dois fenômenos dessa variação.

Segundo Dubois (2001), dialeto é uma forma da língua que possui sua própria sintaxe, fonética e o léxico. Comumente denominado dialeto regional:

O dialeto "é um sistema de signos e regras combinatórias da mesma origem que outro sistema considerado como a língua, mas que se desenvolveu, apesar de não ter adquirido o status cultural e social dessa língua [...]". (DUBOIS, 2001, p. 184).

$\mathrm{Na}$ concepção de Monteiro (2000, p. 46), dialeto é "uma variedade subordinada a uma dada língua, que assim seria entendida como a soma de vários dialetos". È correto afirmar, que o dialeto é uma variante regional usada por determinados grupos causada por fatores sociais, como por exemplo, o preconceito de classes sociais.

Em qualquer área geográfica, pode-se "identificar e descrever um sistema de variedades socioculturais a que denominaríamos de dialetos sociais".(PRETI, 1997, p. 29). Embora não sejam nitidamente distintos como os dialetos geográficos, os dialetos sociais podem ser divididos em pelo menos duas variedades: a língua culta ou a padrão, a qual possui maior prestígio social e mais utilizado em situações formais, e a linguagem popular ou a não padrão considerada a de menor prestígio e utilizada em situações mais coloquiais, menos formais (PRETI, 1997).

Ademais, entre o dialeto social culto e o dialeto social popular, existe o dialeto social comum, um meio-termo entre as duas variedades opostas, a qual obtém uma grande aceitação na população da classe média escolarizada, nos meios de comunicação e até mesmo na escola.

Considerando que a gíria é um recurso predominantemente da língua falada, que, além de fazer parte do vocabulário de muitos falantes - se não todos - é utilizada para reforçar laços sociais e para reafirmar a identidade de uma pessoa. (PRETI, 2000).

Preti (2006, p. 242) afirma que: 
quando se trata da história da gíria, conhecê-la significa penetrar no mundo da marginalidade, na vida dos grupos excluídos da sociedade pela sua própria condição de pobreza ou pelas suas atividades peculiares (não raro ilícitas), os quais buscam com a criação de um vocabulário criptológico uma forma de defesa de suas comunidades restritas. Mas, por outro lado, historicamente, são os mesmos motivos de preservação e segurança que fizeram com que comerciantes ambulantes, mascates, na Idade Média, criassem seus próprios códigos secretos de identificação. E essa gíria da marginalidade e do comércio se mistura também à de um povo surgido na Índia, historicamente discriminado, os ciganos, que, com sua vida nômade, espalharam seu vocabulário em várias áreas da Europa e, posteriormente, da América.

A gíria, segundo Preti (1984), nasce a partir da interação social e, inicialmente, dentro de um determinado grupo social. Em muitos casos, é utilizada para afirmar a identidade de determinado grupo, diferenciando, assim, tal grupo dos demais. Acrescenta o autor que "quanto maior for o sentimento de união que liga os membros de um grupo, tanto mais a linguagem gíria servirá como meio de comunicação, além de forma de autoafirmação". (PRETI, 1984).

A partir do momento que a gíria deixa de pertencer a grupos específicos e começa a ser falada por diversos indivíduos de grupos sociais distintos, ela deixa de ser exclusiva e passa a ser apenas um vocábulo comum da língua:

Portanto, é possível afirmar que só é considerado gíria o vocábulo utilizado por grupos específicos de forma exclusiva, pois, a partir do momento em que a gíria é adotada pelo público geral, ou seja, é vulgarizada, ela passa a ser considerada vocábulo comum da língua. (JUNIOR, 2020, p.44).

O conceito de gíria no dicionário Houaiss (2001, p. 1453), gíria, em sua primeira acepção, significa "uma linguagem informal caracterizada por um vocabulário rico em idiomatismos ${ }^{2}$ metafóricos, jocosos, elípticos, ágeis e mais efêmeros que os da língua tradicional".

É importante ressaltar que muitos confundem a gíria como um regionalismo, um coloquialismo da língua. Contudo, a gíria é considerada como um "código" entre o grupo de seus falantes, uma característica própria de seus usuários. Difere-se dos dialetos que são considerados como regionalismos, uma variação regional da língua de uma determinada região, geralmente falada por indivíduos de classe baixa.

De acordo com Junior (2020), a partir dessas informações, é possível afirmar que:

\footnotetext{
${ }^{2}$ Idiomatismo, conforme o dicionário Houaiss, é o traço ou construção peculiar a uma determinada língua, que não se encontra na maioria dos outros idiomas.
} 
A gíria é uma linguagem utilizada, principalmente, por indivíduos dentro de um grupo. Além disso, a gíria pode variar de acordo com diferentes regiões e épocas. O que não varia, no entanto, é a marginalização e discriminação em relação a ela. (JUNIOR, 2020, p.45).

A gíria para a sociedade elitizada não é considerada como o português padrão, é vista como um ato vulgar. Para os falantes de gírias são vistos como pessoas grosseiras, iletradas, rústicas. Coleman (2012).

\subsubsection{0 papel do Sociolinguista}

A partir das informações do capítulo 3 a linguística tem como seu objeto de estudo a língua. Como foi visto na sessão 3.1 que a língua é um fator social e por conta disso sofre variações porque a língua é falada por pessoas e cada pessoa é um ser único, ou seja, a língua se adéqua ao seu falante.

Partindo desse pressuposto que Labov (2008) iniciou os estudos do uso da língua referindo-se ao meio social de seus falantes, se opondo aos estudos de Saussure (2007) que a creditava que tratava a língua como:

\footnotetext{
"um produto social da faculdade da linguagem e um conjunto de convenções necessárias, adotadas pelo corpo social para permitir o exercício dessa faculdade nos indivíduos". (SAUSSURE, 2007, p. 17).
}

Ainda de acordo com Saussure (2007), a língua é um objeto de natureza homogênea e concreta.

É importante ressaltar que uma definição não necessariamente exclui a outra, apenas significa que, sob o ponto de vista científico dos sociolinguistas, a variação ocupa um lugar central na língua, enquanto que, para a visão Saussuriana, a variação ocupa um lugar não central na língua (BELINE, 2003 apud FIORIN, 2003).

Para fins deste trabalho, será considerada a visão de língua como um sistema heterogêneo e variável, ou seja, com foco no ponto de vista da Sociolinguística Variacionista proposto por Labov (2008), a fim de refletir nas possíveis variações em relação aos personagens da Série "Sintonia", esse tema será abordado no capítulo 5. 
A língua é dotada de variedades que podem ser ocasionadas por inúmeros fatores conforme vimos, na sessão 3.2.1 Por conta dessas variáveis que a comunicação pode não alcançar seu êxito de compreensão da mensagem.

Compete-se ao sociolinguista o papel de gerar informações sobre as possíveis variações da língua. O quanto essas variações podem interferir em uma comunicação. Ademais, seu papel é de verificar e analisar tais variações de acordo com o meio social de se falante.

Um dos métodos dos sociolinguistas é o recurso de gravações entre os falantes de comunidade de fala distintas, a fim de obter um corpus sobre os fatores que desencadeiam tais variações e poder compreendê-las.

Tendo em vista todos os aspectos relacionados à Tradução Intralingual e a Sociolinguística Variacionista e como eles se relacionam diretamente uns com os outros, a presente pesquisa pretende, primeiramente, fazer um levantamento bibliográfico sobre pesquisas e estudos já realizados sobre estes assuntos. Em seguida, analisarei no capítulo 5 os aspectos citados acima em relação à Série "Sintonia", além de apontar, por meio de um questionário com pessoas de estados diferentes - do Rio de Janeiro e Bahia - como seria realizada uma possível Tradução entre essas regiões. Fazendo, assim, uma pesquisa sobre a variação linguística e apresentando como esse processo afetaria a Tradução Intralingual. 


\section{METODOLOGIA}

Classifico o presente trabalho dentro da abordagem qualitativa (DENZIN \& LINCOLN, 2006). Assim, foi realizada uma pesquisa bibliográfica para levantamento de referências teóricas em relação que conceituam o que é a Tradução e mais precisamente a Tradução Intralingual e a Sociolinguística Variacionista. Através dos construtos teóricos apresentados na fundamentação teórica que faço as análises das cenas da série "Sintonia", assim como de um questionário realizado com pessoas de estados distintos (Rio de Janeiro e Bahia). Considero como dados primários da pesquisa algumas cenas do primeiro episódio selecionados da Série "Sintonia".

Assim, no capítulo 5 será realizada uma análise do primeiro episódio da série "Sintonia", através de algumas cenas transcritas. Desse modo, será possível ser feita uma análise comparativa entre as maneiras de se pronunciar a mesma expressão por pessoas de regiões, de classes sociais, e de faixa etárias diferentes. Com a finalidade de entender as variações linguísticas e como elas podem afetar o processo tradutório do tradutor ao coletar informações ao fazer uma Tradução Intralingual. No mesmo capítulo, ainda terá a analise da tabela de expressões e gírias retiradas das falas dos personagens. Por fim, no capítulo 6 será apresentada a conclusão deste projeto.

\subsection{A série "Sintonia"}

A série é original da Netflix, com a criação em 2019 produzido por kondZilla, Guilherme Quintelha e Felipe Braga. Atualmente, tem disponível na plataforma apenas a primeira temporada contabilizando 6 episódios. Seu enredo é baseado em drama e crimes. O elenco principal formado por Christian Malheiros (Nando), Jottapê (Doni) e Bruna Mascarenhas (Rita). A história se passa na quebrada em São Paulo. (KONDZILLA, 2019). 


\subsection{Enredo}

O contexto da série é embasada em três jovens amigos criados juntos na quebrada de São Paulo que correm atrás de seus sonhos rodeados por música, drogas e religião.

A Sinopse do primeiro episódio se chama "Pegaram a Cacau". Doni tem esperança de ser um astro de funk. Nando tenta fazer carreira no tráfico. Rita se preocupa com uma amiga.

Durante toda a primeira temporada a história é contada em São Paulo, principalmente na quebrada onde os três jovens residem. Na quebrada cada jovem possui as suas dificuldades; todavia, nada impede que busquem pelos seus sonhos, ir atrás da felicidade. Contudo, mesmo diante das circunstâncias a amizade deles sempre prevalece.

Nesse primeiro episódio, uma gravadora procura o Doni para conversarem sobre a sua nova música. Antes mesmo de conversarem Doni descobre que a sua música foi roubada por outra Mc que acaba gravando e lançando-a. Nesse momento, seus sonhos são destruídos, porém Doni decide ir atrás de seus direitos e não deixa que nada e ninguém tirem seu sonho de virar um Mc de funk. Seus amigos entram juntos nessa jornada e não deixam ele desistir.

Seu amigo Nando encara outra realidade, quer ser reconhecido pelos chefões do tráfico e decide fazer uma prova de vida, para que reconhecessem a sua fidelidade eliminando um policial que estava trazendo problemas para a quebrada. Mesmo com todas as dificuldades a sua volta, nunca deixou de ajudar os seus amigos quando precisavam dele.

Já a Rita neste episódio perde uma amiga, ela acabou desaparecendo quando foram trabalhar juntas. Ela passa esse episódio tentando encontrar a amiga, que foi sem sucesso, a qual foi presa pelos fiscais com as mercadorias e a maconha da amiga e a Rita não viu. Mesmo com a sua dificuldade cotidiana, não deixa de ajudar o seu amigo Doni, a ir atrás de seu sonho.

A dramaticidade da série é voltada pelas dificuldades que cada jovem sofre ao decorrer dos episódios. A determinação dos personagens em nunca desistir de seus sonhos, é cativante. 


\subsection{Personagens}

O Nando é um garoto com dificuldades financeiras - que piora quando sua filha nasce - e encontra uma solução ao entrar para a vida do crime. Ele faz de tudo para ser reconhecido pelos seus chefes, planeja várias estratégias para ser promovido e subir de cargo dentro da quebrada, ganhar mais responsabilidades e quem sabe virar um chefe do crime organizado. Seu estilo de vida é baseado nas condições que se vive. Seu vocabulário é de acordo com o meio que está inserido, no tráfico de drogas, com uso exagerado de gírias. Veste-se com roupas largas e possui acessórios exuberantes como relógios e cordões.

A segunda personagem é a Rita uma menina órfã que precisa se virar desde nova. Por conta disso, ela passa vender produtos falsificados como camelô. Ela possui um estilo de acordo com a sua situação, se veste com roupas apertadas e curtas. Seu vocabulário é limitado, sem a elitização do português padrão, é provável que o uso exagerado das gírias e a pronunciação das palavras "erradas" são consequências do abandono da escola por causa do trabalho e devido ao contato diário com o português não padrão.

Já o Doni tem um sonho em virar Mc de funk, mesmo que isso desaponte seu pai. Mesmo diante de todas as dificuldades, não desiste em realizar seu sonhos. Seu estilo de vida e vocabulário são baseados em relação com a maneira em que se vive. Mesmo o Doni estudando em escola de classe média alta, fora da quebrada, seu linguajar não corresponde juntamente aos colegas de classe, ao contrário seu linguajar é com uso de gírias que pertencem ao mundo do funk, onde somente aquela comunidade de fala compreende.

Cacau é um personagem coadjuvante, amiga da Rita que não aguenta mais a dependência de sua mãe e se oferece ir trabalhar junto com a amiga. Neste primeiro episódio, ao ir trabalhar com a amiga, Cacau acaba sendo presa pelos fiscais e a mandam para um reformatório para menores infratores. Cacau e Rita são muitas parecidas no estilo de se vestir, com roupas curtas e apertadas, além de possuir um vocabulário não elitizado, com bastantes gírias da região em questão.

O usuário de drogas é um personagem que não é nomeado na série, que vai de encontro ao Nando e sua família num posto de saúde querendo comprar drogas e é repreendido pelo Nando. Mesmo não sendo nomeado foi utilizado neste trabalho na cena 2 transcrita na sessão 5.1 . 
Cabe ressaltar que há outros personagens no decorrer da série; no entanto, para analise deste trabalho será apenas usado dois personagens principais e dois personagens coadjuvantes como objeto de estudo nas cenas transcritas no capítulo 5. 


\section{ANÁLISE DAS CENAS DA SÉRIE "SINTONIA"}

De acordo com as informações apresentadas no capítulo 3.2.1, as variações linguísticas ou sociais ocorrem por inúmeros fatores. Assim, é correto afirmar que o papel do tradutor, principalmente o iniciante, ao se deparar com tais variações numa Tradução Intralingual não é uma tarefa simples, visto que traduzir da língua-fonte para a língua-meta já uma tarefa árdua. Ao se tratar de fazer uma tradução interna, para a mesma língua é consideravelmente um processo mais complicado.

A princípio foi escolhido o primeiro episódio da Série "Sintonia" como base de estudo para as variações linguísticas existentes entre os personagens. Algumas cenas foram selecionadas, a fim de proporcionarem uma análise aprofundada sobre tais variações de acordo com as características dos personagens. E como tais variações afetariam o processo tradutório do tradutor.

O objetivo deste presente trabalho, não é de fazer uma Tradução Intralingual e muito menos de apontar erros do original, mas sim de apresentar que há uma variedade na língua e que dependendo da região pode não haver a comunição por conta das diferenças sociais e culturais.

A partir dessas informações, que esta pesquisa pretende analisar algumas cenas transcritas do primeiro episódio da Série "Sintonia" em áudio original (PT), com o intuito de refletir sobre as variações linguísticas presentes em relação aos personagens da Série.

As cenas do primeiro episódio foram transcritas e apresentadas em formas de quadros para que assim seja possível e de fácil identificação as informações contidas neles. A título de exemplo, o Quadro 1, abaixo.

\begin{tabular}{|l|l|l|l|l|}
\hline Episódio & Marcação & Personagem & Linha & (Original) \\
\hline & & & & \\
\hline
\end{tabular}

Quadro 1 - Exemplo da transcrição das cenas

Como foi visto, o Quadro 1, tem a finalidade de detalhar as informações transcritas das cenas como o "Episódio", a "Marcação", o "Personagem", a "Linha" e o "Original". Na primeira coluna "Episódio" será indicado qual temporada e qual 
episódio à cena foi retirada, por exemplo, se foi transcrita uma cena da temporada 1 , no episódio 3, será representado nesta coluna por "T1:E3".

Na coluna "Marcação", será representada no formato HH:MM:SS, onde HH é em horas, o MM é em minutos e SS é segundos, o tempo de entrada da primeira e da última fala no original. Na coluna "Personagem", será indicado de qual personagem foi retirada a fala no original.

$\mathrm{Na}$ coluna "Linha", será representada a quantidade de linhas por fala dos personagens. Na ultima coluna "Original", serão representados as transcrições das falas dos personagens no formato do original em Português (PT-BR).

Dessa forma, na sessão 5.1 serão feitas as transcrições das cenas e as analises das informações contidas nela.

\subsection{Transcrições das cenas}

\section{- Cena 1}

As personagens Rita e Cacau conversam sobre irem trabalharem juntas. Rita, uma das personagens principais da série, vive sozinha, é independente busca o seu próprio sustento, precisando vender produtos falsificados na rua. O seu vocabulário e estilo de roupa são de acordo com a condição social que está inserida, além de residir na quebrada, frequentar bailes funk e ainda ser camelô, ou seja, uma menina criada nas ruas provavelmente sem ter concluído o ensino médio. A sua amiga Cacau possui um estilo de vestir muito parecido com da Rita, devido a quebrada onde residem. No entanto, a Cacau mora com a mãe que tenta impor limites na maneira de falar e se vestir também e não gosta que fique tanto na rua diferente da Rita que não tem pais para impor nada a ela, vive da maneira que bem entender.

\begin{tabular}{|c|l|l|l|l|}
\hline Episódio & Marcação & Personagem & Linha & Original \\
\hline \multirow{3}{*}{ T1:E1 } & $04: 47$ & Cacau & 1 & Eu posso marretar com você? \\
\cline { 3 - 5 } & & Rita & 2 & $\begin{array}{l}\text { Claro que pode. Sua mãe já me odeia } \\
\text { mesmo. }\end{array}$ \\
\cline { 3 - 5 } & & Cacau & 3 & Ah eee. \\
\cline { 3 - 5 } & Rita & 4 & $\begin{array}{l}\text { Mas oh, não é oba oba não, vai ter que } \\
\text { ralar. A gente se encontra perto da } \\
\text { barbearia, pode ser? }\end{array}$ \\
\hline
\end{tabular}




\begin{tabular}{l|l|l|l} 
04:59 & Cacau & 6 & Ta. Fechou.
\end{tabular}

Quadro 2 - Transcrição da cena 1

Nesta cena, observa-se um linguajar específico das quebradas do estado de São Paulo, ou seja, em outras regiões talvez a mensagem possa ser não compreendida devido à variação linguística.

Na linha 1, a expressão "posso marretar com você" é bastante específica daquela região em questão, ou seja, uma pessoa de outra localidade não receberia a mensagem e não haveria uma comunicação. A expressão "marretar" tem o sentido de poder ir trabalhar junto com a outra pessoa.

Na linha 4, a expressão "ralar" tem o sentido de que o trabalho vai ser bem difícil, que vai dar muito trabalho. Já a expressão "oba oba", tem o sentido de que ir trabalhar nas ruas não é algo fácil, não é moleza como pensam, e sim que é um trabalho árduo como qualquer um.

$\mathrm{Na}$ linha 6, a expressão "fechou" tem o sentido de marcar/selar um compromisso.

Na concepção de Monteiro (2000) o dialeto é considerado como uma variação regional. É correto afirmar que essas expressões usadas pelos personagens não deixam de serem dialetos específicos daquela região.

Ao se deparar com os dialetos numa Tradução Intralingual, é dever do tradutor de coletar quaisquer dados sobre tanto os dialetos da língua-fonte quanto da língua-meta, assim, no seu corpus terá as informações sobre as possíveis equivalências dos dialetos ou não. Desse modo, quando for traduzir necessitará apenas de verificar o corpus.

\section{- Cena 2}

Um dos personagens principais o Nando está no médico com a família, quando um usuário de drogas vai até a ele. Nando entra para a vida do crime para ganhar dinheiro logo assim quando a sua namorada engravida. O seu estilo de vida, de se vestir e o seu vocabulário são parte da influência de residir na quebrada e, além disso, por ser um traficante, um dos homens que toma conta das vendas de drogas. 


\begin{tabular}{|c|c|c|c|c|}
\hline Episódio & Marcação & Personagem & Linha & Original \\
\hline \multirow{8}{*}{$\mathrm{T} 1: \mathrm{E} 1$} & $05: 03$ & Usuário & 1 & E ai Nando, beleza mano? \\
\hline & & Nando & 2 & Beleza. \\
\hline & & Usuário & $\begin{array}{l}3 \\
4\end{array}$ & $\begin{array}{l}\text { Po, deixa eu falar é com você mesmo. } \\
\text { Queria a paradinha. Você não tem um pino } \\
\text { para me salvar, mano? Qualquer coisinha. }\end{array}$ \\
\hline & & Nando & $\begin{array}{l}5 \\
6\end{array}$ & $\begin{array}{l}\text { Chega ai parça. } \\
\text { Ta metendo o louco caralho? }\end{array}$ \\
\hline & & Usuário & 7 & Porque, mano? \\
\hline & & Nando & 8 & $\begin{array}{l}\text { Porra, tu não viu minha família ai não } \\
\text { caralho. Respeito, porra. }\end{array}$ \\
\hline & & Usuário & 9 & Poxa, mas tu não esta no bagulho, truta? \\
\hline & 05:28 & Nando & $\begin{array}{l}10 \\
11\end{array}$ & $\begin{array}{l}\text { Vem cá, tu não é usuário meu irmão? } \\
\text { Tu sabe onde é a lojinha ta ligado. Mete o } \\
\text { pé. }\end{array}$ \\
\hline
\end{tabular}

Quadro 3 - Transcrição da cena 2

Nesta cena, é possível observar um linguajar diferente do padrão, com uso de gírias, um vocabulário bem específico. Um indivíduo fora do meio em questão, da quebrada e do tráfico de drogas, fora da comunida de fala não compreenderia a mensagem a ser transmitida na comunicação. O que é ocasionado pela variação linguística, ou seja, maneiras diferentes de dizer a mesma expressão. Não há só uma língua padrão, ela é composta por suas variantes mesmo que seja considerada uma língua não padrão.

$\mathrm{Na}$ linha 4, observa-se um linguajar que é específico daquela região quando o assunto se refere a drogas. Entende-se que a comunicação não almejaria seu objetivo se houvesse um indivíduo de outro estado, por exemplo, não entenderia a mensagem a ser transmitida por aquele usuário de drogas. O sentido da gíria "pino", nessa linha, é o mesmo de droga, o usuário quer comprar uma droga ali mesmo.

Na linha 9, há uma gíria, "truta", que não se refere a drogas, porém é bastante específica do estado de São Paulo. A expressão ou gíria "truta" para os paulistanos tem o sentido de mano/irmão.

Segundo Preti (1984), a gíria é uma característica não somente de uma determinada região, mas também exclusiva de uma comunidade de fala, onde indivíduos de outras faixas etárias ou até mesmo com a mesma faixa etária; no entanto, de região diferente não compreenderia a mensagem. 
Cabe ao tradutor coletar todas as informações sobre as gírias da língua-fonte, guardar no corpus, e tentar encontrar equivalências na língua-meta, caso não as encontre cabe o tradutor escolher quais gírias serão usadas, sem que percam o sentido do original.

\section{- Cena 3}

Rita e Cacau estão vendendo os produtos numa passarela. Nessa cena, é possível observar o tipo de vocabulário que usam para tentar vender tais produtos. Um vocabulário com escolhas lexicais condizentes ao que é esperado pelos clientes em potencial, com erros na pronúncia, ou seja, esse jogo de palavras que usam pode ser para impressionarem os compradores ou será devido à falta de letramento das personagens?

\begin{tabular}{|c|c|c|c|c|}
\hline Episódio & Marcação & Personagem & Linha & Original \\
\hline \multirow{9}{*}{ T1:E1 } & 13:03 & Rita & $\begin{array}{l}1 \\
2 \\
3\end{array}$ & $\begin{array}{l}\text { Bom dia rapaziada, tudo bem? } \\
\text { Aqui ó, três lente, } 15 \text { contos. } \\
\text { Três lente, kit completo com três lente. }\end{array}$ \\
\hline & & Cacau & $\begin{array}{l}4 \\
5\end{array}$ & $\begin{array}{l}\text { Sabe quanto ta esse produto na internet? } \\
\text { Sabe quanto? }\end{array}$ \\
\hline & & Rita & 6 & Fala pra eles. \\
\hline & & Cacau & 7 & 30 conto. \\
\hline & & Rita & $\begin{array}{l}8 \\
9\end{array}$ & $\begin{array}{l}30 \text { conto. } \\
\text { Mas aqui na minha mão, senhora, na minha } \\
\text { mão, ta Black Friday. }\end{array}$ \\
\hline & & Cacau & 10 & Black Friday. \\
\hline & & Rita & 11 & Vai rolar 15 conto. \\
\hline & & Cacau & 12 & 15 reais. \\
\hline & 13:28 & Rita & $\begin{array}{l}13 \\
14\end{array}$ & $\begin{array}{l}\text { Fisheye, macro e wide. } \\
\text { E agora só falta você meu amigo. }\end{array}$ \\
\hline
\end{tabular}

Quadro 4 - Transcrição da cena 3

Nesta cena é notório que a estrutura não está alinhada ao português padrão. A escolha lexical está condizente com a comunidade de fala em quais as personagens estão inseridas. Vale ressaltar, mesmo com a escolha desse vocabulário não padrão das personagens há uma comunicação entra elas, conseguem entender a mensagem que foi transmitida e, além disso, por conta do cenário em questão o uso desse vocabulário pode ter sido proposital, um marketing, 
atraindo a clientela. No entanto, observa-se que mesmo sendo proposital esse vocabulário é um dos fatores que desencadeia a variação linguística.

Nas linhas 2,3,7,8 e 13, observa-se o emprego de algumas palavras pronunciadas de certa forma errada conforme os dicionários alinhados ao português padrão pela gramática, por não estarem de acordo com as flexões dos substantivos, ou seja, em questão de número. A falta do uso do plural nas palavras chama atenção, podendo ser uma questão de variação linguística social, cultural e/ou geográfica.

Nas linhas 10 e 11, é necessário entender que a diferença entre a língua falada e a escrita existe. Para fazer a transcrição foi preciso ser a fiel a escrita dos estrangeirismos; todavia, as pronunciações dessas palavras pelas personagens foram de forma incorretas, apenas adaptaram os estrangeirismos ao seu idioma.

Dessa forma, é difícil transcrever a língua falada para a língua escrita. Segundo Oliveira (2018), na língua falada é possível usar o recurso dos gestos e expressões faciais ao pronunciar uma palavra, diferente da escrita onde esse recurso não é possível. Por conta disso, a transcrição da língua falada para a escrita é um processo complicado para o sociolinguista.

\subsubsection{Personagens das cenas}

Vale ressaltar que há mais personagens ao decorrer da primeira temporada da Série "Sintonia", porém para este objeto de estudo das cenas transcritas da sessão 5.1 , foi-se usado apenas 2 dois 3 personagens principais e 2 personagens coadjuvantes.

O Nando é um dos personagens principais, que encontrou na vida do crime uma saída para sustentar a sua família, pois quando soube que seria pai colocou como sua prioridade o sustento e não o tipo de trabalho. Por conta, da influência na vida do crime sua maneira de se vestir e se pronunciar refletem esse meio.

A segunda personagem principal é a Rita, depois que sua mãe falece e seu pai desaparece passou a ser independente, visa apenas o seu sustento. Começa trabalhar como camelô e larga os estudos para se sustentar. Seu linguajar e vestuário são refletidos da sua condição social. 
Cacau é uma personagem coadjuvante, amiga da Rita que pede para ir trabalhar na rua com ela e acaba desaparecendo.

Usuário de drogas, sem identificação, é um dos personagens coadjuvantes que vai até o Nando para tentar comprar drogas.

\section{2 Questionário}

O objetivo desta tabela é de analisar as diferenças culturais dentro da língua portuguesa devido às variações linguística através de expressões retiradas dos episódios da Série "Sintonia". O intuito será de refletir sobre as possíveis variações linguísticas existentes entre estados diferentes, no caso deste trabalho uma comparação com as expressões e das gírias dos personagens que são de São Paulo, áudio original da Série, entre os estados do Rio de Janeiro e da Bahia. Conforme veremos na sessão 5.2.2.

$\mathrm{Na}$ Tabela 1, serão representadas as expressões e das gírias retiradas às falas dos personagens da serie "Sintonia" e, do original, os entrevistados preencherão as linhas conforme as expressões e gírias de seus estados.

Tabela 1 - Representação das expressões e das gírias

\begin{tabular}{|l|l|l|}
\hline São Paulo (original) & Rio de Janeiro & Bahia \\
\hline pega visão & & \\
\hline $\begin{array}{l}\text { aqui não da para ficar } \\
\text { moscando não, parceiro }\end{array}$ & & \\
\hline $\begin{array}{l}\text { se não tem um pino para } \\
\text { me salvar mano }\end{array}$ & & \\
\hline posso marretar com você? & & \\
\hline isso é pica parca & & \\
\hline pegar as fitas contigo & & \\
\hline saquei ele da loja & & \\
\hline qual é dessa fita ai & & \\
\hline essa ta o verde heim & & \\
\hline ta chave & & \\
\hline $\begin{array}{l}\text { só preciso da peça e do } \\
\text { cavalo }\end{array}$ & & \\
\hline não vai ramelar & & \\
\hline ta pousado nas ideias & & \\
\hline te levar para as ideias & & \\
\hline mete marcha & & \\
\hline
\end{tabular}


A análise do questionário com 4 perguntas será mostrado na sessão 5.2.2.2, a fim de analisar as possíveis variações de acordo as diferenças linguísticas regionais. $O$ apêndice com as perguntas será encontrado no final do presente trabalho.

\subsubsection{Contexto do Questionário}

O questionário foi entregue por e-mail para nove pessoas, assim o intuito era que preenchessem primeiro a tabela de expressões e das gírias e logo que respondessem as quatro perguntas. Foram entregues para cinco homens e quatro mulheres; quatro homens e duas mulheres do Rio de Janeiro (RJ) e um homem e duas mulheres da Bahia (BA) com faixa etária, sexo, classe social e regiões diferentes. A fim de analisar as variedades de acordo com o meio que cada indivíduo está inserido, posto que a faixa etária, o sexo, a classe social e a região dos falantes podem ser determinantes para uma variação linguística e social.

Foi determinado sigilo sobre a identidade dos indivíduos revelando somente a sua idade, sexo, região e classe social. Assim, para a identificação dos entrevistados será usado à sigla $\mathrm{E} 1 \mathrm{e}$, assim respectivamente.

Cabe ressaltar que os dados contidos nos quadros são apenas de reflexão sobre as diferenças sócias e culturais entre os entrevistados e como podem desencadear uma variação linguística.

No quadro 5, apresenta a faixa etária dos nove indivíduos entrevistados. Dos nove entrevistados, nota-se que a faixa etária entre eles são diferentes, a fim de obter um resultado sobre a variação linguística, visto que a faixa etária é um fator determinante para a variação.

\begin{tabular}{|l|l|}
\hline Idade (em anos) & Total \\
\hline 10 a 20 & 4 \\
\hline 20 a 30 & 2 \\
\hline 30 a 40 & 3 \\
\hline Totais & 9 \\
\hline
\end{tabular}

No quadro 6, apresenta o sexo dos entrevistados, nota-se que cinco entrevistados são do sexo masculino (M), representando a maioria dos 
entrevistados, e quatro entrevistados são do sexo feminino $(F)$, representando a menoria dos entrevistados.

O sexo é um dos fatores determinantes para uma variação linguística, neste caso, os entrevistados tendo sexos diferentes dos personagens podem não compreender a mensagem.

\begin{tabular}{|l|l|}
\hline Sexo & Total \\
\hline $\mathrm{M}$ & 5 \\
\hline $\mathrm{F}$ & 4 \\
\hline Totais & 9 \\
\hline
\end{tabular}

Quadro 6 - Sexo dos entrevistados

No quadro 7, é possível observar que cada entrevistado possui uma escolaridade diferente, ou seja, a classe social entre os entrevistados por serem distintas e podem influenciar na variação linguística.

Neste caso o nível de escolaridade dos entrevistados é de uma importância para esta análise, visto que o nível de escolaridade dos personagens é baixo. Por conta disso, de acordo com a escolaridade dos entrevistados será possível analisar se compreenderiam ou não a mensagem das expressões e gírias retiradas da série.

\begin{tabular}{|c|c|c|}
\hline$E$ & Escolaridade & Total \\
\hline E1 & Nível Básico & 1 \\
\hline E2 & $\begin{array}{l}\text { Cursando Nível } \\
\text { Médio }\end{array}$ & 1 \\
\hline E3 & $\begin{array}{l}\text { Nível Médio } \\
\text { Completo }\end{array}$ & 1 \\
\hline E4 & $\begin{array}{l}\text { Cursando } \\
\text { Superior }\end{array}$ & 1 \\
\hline E5 & $\begin{array}{l}\text { Superior } \\
\text { Completo }\end{array}$ & 1 \\
\hline E6 & $\begin{array}{l}\text { Cursando Nível } \\
\text { Médio }\end{array}$ & 1 \\
\hline E7 & $\begin{array}{l}\text { Cursando } \\
\text { Superior }\end{array}$ & 1 \\
\hline E8 & $\begin{array}{l}\text { Cursando } \\
\text { Fundamental } 2\end{array}$ & 1 \\
\hline \multirow[t]{2}{*}{ E9 } & $\begin{array}{l}\text { Nível Médio } \\
\text { Completo }\end{array}$ & 1 \\
\hline & Totais & $?$ \\
\hline
\end{tabular}


No quadro 8, apresenta a Profissão de cada entrevistado, nota-se que todos são diferentes. Vale ressaltar, que a profissão dos indivíduos é de acordo com a ordem de aparição no quadro de Escolaridade, ou seja, o entrevistado com Nível Básico, no quadro 7, é o Atendente, no quadro 8, e assim respectivamente.

\begin{tabular}{|c|c|c|}
\hline $\mathrm{E}$ & Profissão & Total \\
\hline E1 & Atendente & 1 \\
\hline E2 & Estudante & 1 \\
\hline E3 & Artesã & 1 \\
\hline E4 & $\begin{array}{l}\text { Gerente } \\
\text { Executivo }\end{array}$ & 1 \\
\hline E5 & Psicóloga & 1 \\
\hline E6 & Estudante & 1 \\
\hline E7 & Professor de LI & 1 \\
\hline E8 & Estudante & 1 \\
\hline \multirow[t]{2}{*}{ E9 } & Babá & 1 \\
\hline & Totais & $?$ \\
\hline
\end{tabular}

No quadro 9, nota-se que os entrevistados são de estados diferentes. Seis entrevistados são do Rio de Janeiro, representando a maioria, e três entrevistados são da Bahia, representando a menoria.

A região é um fator importante para a varação linguística, posto que cada região tem seu dialeto próprio, dificultando a mensagem ser compreendida por um falante de outra região. No caso desses entrevistados que pertencem a dois estados distintos, o objetivo era de observar e refletir como as expressões e gírias de São Paulo ficariam entre os cariocas e os baianos e se haveria ou não equivalências entre elas.

\begin{tabular}{|l|l|}
\hline Estado & Total \\
\hline RJ & 6 \\
\hline BA & 3 \\
\hline Totais & 9 \\
\hline
\end{tabular}

Quadro 9 - Região dos entrevistados 


\subsubsection{Tabela de expressões e gírias}

Nesta sessão será mostrada a representação das expressões e gírias, confirme a Tabela 1 na sessão 5.2, através da experiência sócia e cultural de cada entrevistado de acordo com a sua região.

$\mathrm{Na}$ tabela, todas as expressões e gírias são retiradas das falas dos personagens da Série "Sintonia".

Vale ressaltar, conforme vimos, na sessão 5.3, um questionário foi entregue por e-mail para os nove indivíduos. Primeiro para que preenchessem a tabela de expressões e gírias e depois que respondessem as quatro perguntas.

Vale ressaltar que o objetivo desta tabela não é de pontuar o que é certo ou errado, mas sim de refletir sobre as possíveis variações das expressões e gírias de acordo com a região dos entrevistados.

Conforme vimos na sessão 5.2 à identidade dos entrevistados permanecerá em sigilo e serão identificados como Entrevistado 1 ou por "E1".

- Entrevistado 1

Tabela 2 - Expressões e gírias do Entrevistado 1

\begin{tabular}{|l|l|l|}
\hline São Paulo & Rio de Janeiro & Bahia \\
\hline $\begin{array}{l}\text { pega visão } \\
\text { mosui não da para ficar }\end{array}$ & qual foi & \\
\hline $\begin{array}{l}\text { se não tem um pode dar mole } \\
\text { me salvar mano para }\end{array}$ & tem pó ai não & \\
\hline posso marretar com você? & posso trampar com você & \\
\hline isso é pica parca & essa pica ta foda & \\
\hline pegar as fitas contigo & pega a visão & \\
\hline saquei ele da loja & passa a visão & \\
\hline qual é dessa fita ai & essa tá o trem & \\
\hline essa ta o verde heim & fechamento & \\
\hline ta chave & & \\
\hline $\begin{array}{l}\text { so preciso da peça e do } \\
\text { cavalo }\end{array}$ & vai dar merda heim & \\
\hline não vai ramelar & & \\
\hline ta pousado nas ideias & vamos ali desenrolar & \\
\hline te levar para as ideias & vaza & \\
\hline mete marcha & & \\
\hline
\end{tabular}


Na Tabela 2, observa-se que o E1 é morador do Rio de Janeiro e que não soube identificar a equivalência de algumas expressões e gírias na sua região. Esse fator pode ter acontecido por ele não pertencer à mesma comunidade de fala do personagem, por não ter uma faixa etária equivalente ou até mesmo ser do sexo oposto. É notório que as expressões e gírias do RJ são diferentes das dos personagens que moram em SP, esse fator é devido à variação linguística, ou seja, que cada região possui a sua determinada maneira de dizer tais expressões e que pode variar de acordo com as determinantes que vimos na sessão 3.2.1.

- Entrevistado 2

Tabela 3 - Expressões e gírias do Entrevistado 2

\begin{tabular}{|l|l|l|}
\hline São Paulo & Rio de Janeiro & Bahia \\
\hline pega visão & se liga & \\
\hline $\begin{array}{l}\text { aqui não da para ficar } \\
\text { moscando não, parceiro }\end{array}$ & da mole não & \\
\hline $\begin{array}{l}\text { se não tem um pino para } \\
\text { me salvar mano }\end{array}$ & & \\
\hline posso marretar com você? & posso ralar contigo & \\
\hline isso é pica parca & maneiro & \\
\hline pegar as fitas contigo & pegar as paradas contigo & \\
\hline saquei ele da loja & expulsei ele a força & \\
\hline qual é dessa fita ai & qual foi da parada ai & \\
\hline essa ta o verde heim & essa tá boa & \\
\hline ta chave & suave & \\
\hline $\begin{array}{l}\text { so preciso da peça e do } \\
\text { cavalo }\end{array}$ & & \\
\hline não vai ramelar & não da pra trás & \\
\hline ta pousado nas ideias & te levar pra boca & \\
\hline te levar para as ideias & mete o pé & \\
\hline mete marcha &
\end{tabular}

Na Tabela 3, nota-se que este E2 que também é do RJ não encontrou uma equivalência para a expressão "só preciso da peça e do cavalo" juntamente como o E1 também não encontrou. Neste caso, como ambos são moradores do mesmo estado, pode-se dizer que nesta região não há essa expressão, ou que esses entrevistados não pertencem a uma comunidade de fala que reconheça tal expressão, ou que as suas faixas etárias sejam distintas em relação aos personagens que são bem jovens. Todos esses fatores podem influenciar na variação. 
- Entrevistado 3

Tabela 4 - Expressões e gírias do Entrevistado 3

\begin{tabular}{|l|l|l|}
\hline São Paulo & Rio de Janeiro & Bahia \\
\hline $\begin{array}{l}\text { pega visão } \\
\text { mosui não da para ficar }\end{array}$ & fala pae \\
\hline $\begin{array}{l}\text { se não tem um pino para } \\
\text { me salvar mano }\end{array}$ & não pode vacilar \\
\hline posso marretar com você? & & tem uma parada ai \\
\hline isso é pica parca & brocar \\
\hline pegar as fitas contigo & é barril \\
\hline saquei ele da loja & se ligou ai \\
\hline qual é dessa fita ai & \\
\hline essa ta o verde heim & & \\
\hline ta chave & & ta blombrado tio? \\
\hline $\begin{array}{l}\text { so preciso da peça e do } \\
\text { cavalo }\end{array}$ & & \\
\hline não vai ramelar & & cagou no pau \\
\hline ta pousado nas ideias & & \\
\hline te levar para as ideias & & da um papo pae \\
\hline mete marcha & & se adianta \\
\hline
\end{tabular}

$\mathrm{Na}$ tabela 4, é notório que o E3 obteve algumas dificuldades em encontrar equivalências na sua região que é a BA. Vale ressaltar, que este entrevistado é da mesma faixa etária que a dos personagens da série, neste caso é correto a firmar que mesmo sendo jovem ele não pertence à mesma comunidade de fala dos personagens. O meio social deste entrevistado não é o mesmo que a dos personagens da série, por conta disso não está habituado com esse linguajar diferente do seu dia a dia, mesmo sendo da mesma faixa etária.

- Entrevistado 4

Tabela 5 - Expressões e gírias do Entrevistado 4

\begin{tabular}{|l|l|l|}
\hline São Paulo & Rio de Janeiro & Bahia \\
\hline pega visão & olha ae \\
\hline $\begin{array}{l}\text { aqui não da para ficar } \\
\text { moscando não, parceiro }\end{array}$ & & \\
\hline $\begin{array}{l}\text { se não tem um pino para } \\
\text { me salvar mano }\end{array}$ & tem uma parada ai \\
\hline posso marretar com você? & & borá ali \\
\hline isso é pica parca & daora \\
\hline pegar as fitas contigo & & \\
\hline saquei ele da loja & & o paio \\
\hline
\end{tabular}




\begin{tabular}{|l|l|l|}
\hline qual é dessa fita ai & & \\
\hline essa ta o verde heim & & \\
\hline ta chave & & de boa \\
\hline $\begin{array}{l}\text { so preciso da peça e do } \\
\text { cavalo }\end{array}$ & \\
\hline não vai ramelar & & \\
\hline ta pousado nas ideias & & \\
\hline te levar para as ideias & & \\
\hline mete marcha & & sai fora \\
\hline
\end{tabular}

Nota-se que na Tabela 5 o E4 praticamente não encontrou equivalência das expressões e gírias de acordo com a sua região. Este entrevistado é de faixa etária mais alta que as dos personagens da Série, por conta disso não entendeu a mensagem das expressões e gírias, não pertence a essa comunidade de fala. Além disso, de acordo com os Quadros 7/8, o E4 é Gerente Executivo, Cursando Superior, ou seja, seu convívio social é totalmente diferenciado em comparação com os personagens. É correto afirmar que, por conta disso que não compreendeu muito bem a mensagem das expressões e gírias para que assim pudesse encontrar equivalências na sua região. Esses são um dos fatores que ocasionam a variação linguística.

- Entrevistado 5

Tabela 6 - Expressões e gírias do Entrevistado 5

\begin{tabular}{|l|l|l|}
\hline São Paulo & Rio de Janeiro & Bahia \\
\hline pega visão & $\begin{array}{l}\text { Pega a visão (mesmo } \\
\text { sentido) }\end{array}$ \\
\hline $\begin{array}{l}\text { aqui não da para ficar } \\
\text { moscando não, parceiro }\end{array}$ & $\begin{array}{l}\text { Ficar moscando (mesmo } \\
\text { sentido) ou então "Não dá } \\
\text { pra ficar vacilando". }\end{array}$ \\
\hline $\begin{array}{l}\text { se não tem um pino para } \\
\text { me salvar mano }\end{array}$ & $\begin{array}{l}\text { Usa-se pino ou uma } \\
\text { carreira. }\end{array}$ \\
\hline posso marretar com você? & $\begin{array}{l}\text { "Posso fazer uma fita com } \\
\text { você?" ou então "Posso } \\
\text { levantar uma grana com } \\
\text { você?" }\end{array}$ \\
\hline isso é pica parca & "Isso é batendo" \\
\hline pegar as fitas contigo & "Pegar o bagulho." \\
\hline saquei ele da loja & $\begin{array}{l}\text { "Botei pra correr" ou "botei } \\
\text { pra partir a mil" }\end{array}$ \\
\hline qual é dessa fita ai & "Qual foi a dele (a)?" \\
\hline essa ta o verde heim & "Tá batendo." \\
\hline ta chave & "Tá de boa" \\
\hline so preciso da peça e do & "Só preciso da peça" \\
\hline
\end{tabular}




\begin{tabular}{|l|l|l|}
\hline cavalo & \\
\hline não vai ramelar & "Não vai deixar em falta." \\
\hline ta pousado nas ideias & "Tá castelando." \\
\hline te levar para as ideias & "Cabojar" \\
\hline mete marcha & "mete o pé" \\
\hline
\end{tabular}

Vale ressaltar que na Tabela 6 o E5 é Psicólogo que trata de jovens infratores em Feira de Santa na BA. As respostas das expressões e das gírias foram de acordo com os jovens que fazem sessão com o próprio.

É interessante observar que preencheram todas as expressões e gírias, podemos dizer que esses jovens pertencem à mesma comunidade de fala dos personagens da Série, por terem faixas etárias parecidas mesmo que sejam de regiões diferentes, entenderam a mensagem. Contudo, é notório que mesmo que tenham preenchido tudo, as expressões e as gírias não são as mesmas, e isso ocorre porque cada região tem a sua maneira especifica de falar certas expressões.

- Entrevistado E6

Tabela 7 - Expressões e gírias do Entrevistado 6

\begin{tabular}{|l|l|l|}
\hline São Paulo & Rio de Janeiro & Bahia \\
\hline pega visão & fica ligado & \\
\hline $\begin{array}{l}\text { aqui não da para ficar } \\
\text { moscando não, parceiro }\end{array}$ & & \\
\hline $\begin{array}{l}\text { se não tem um pino para } \\
\text { me salvar mano }\end{array}$ & tem pó ai & \\
\hline posso marretar com você? & & \\
\hline isso é pica parca & ta difícil & \\
\hline pegar as fitas contigo & & \\
\hline saquei ele da loja & & \\
\hline qual é dessa fita ai & o que ta acontecendo & \\
\hline essa ta o verde heim & essa ta boa & \\
\hline ta chave & tudo certo & \\
\hline $\begin{array}{l}\text { so preciso da peça e do } \\
\text { cavalo }\end{array}$ & & \\
\hline não vai ramelar & não da pra trás & \\
\hline ta pousado nas ideias & & \\
\hline te levar para as ideias & & \\
\hline mete marcha & & \\
\hline
\end{tabular}

$\mathrm{Na}$ Tabela 7, nota-se que o E6 encontrou dificuldades ao correlacionar as gírias de São Paulo com as do RJ. Esse fator pode ter ocorrido pelo fato desse E6 não pertencer à mesma comunidade de fala do personagem da série, mesmo ele 
sendo de faixa etária próxima, seu grupo social é distinto, de acordo com os Quadros 7/8 o E6 é Estudante do Ensino Médio. Desse modo, não compreende as expressões e gírias que pertencem a grupo especifico, neste caso ao mundo do tráfico de drogas.

- Entrevistado E7

Tabela 8 - Expressões e gírias do Entrevistado 7

\begin{tabular}{|l|l|l|}
\hline São Paulo & Rio de Janeiro & Bahia \\
\hline pega visão & presta atenção & \\
\hline $\begin{array}{l}\text { aqui não da para ficar } \\
\text { moscando não, parceiro }\end{array}$ & $\begin{array}{l}\text { aqui não da para dar mole, } \\
\text { fica esperto }\end{array}$ & \\
\hline $\begin{array}{l}\text { se não tem um pino para } \\
\text { me salvar mano }\end{array}$ & tem algum pó ai não? & \\
\hline posso marretar com você? & posso trampar com você? & \\
\hline isso é pica parca & isso é problema & \\
\hline pegar as fitas contigo & pegar lá com você & \\
\hline saquei ele da loja & tirei ele daqui & \\
\hline qual é dessa fita ai & o que aconteceu? & \\
\hline essa ta o verde heim & essa ta boa & \\
\hline ta chave & ta tranquilo & \\
\hline $\begin{array}{l}\text { só preciso da peça e do } \\
\text { cavalo }\end{array}$ & só preciso de uma arma & \\
\hline não vai ramelar & não vai sacanear & \\
\hline ta pousado nas ideias & ta viajando & \\
\hline te levar para as ideias & vamos ali na boca & \\
\hline mete marcha & vai embora logo & \\
\hline
\end{tabular}

Nesta Tabela 8, observa-se que este entrevistado conseguiu correlacionar todas as expressões e gírias de SP com as do RJ. Cabe dizer que o E7 e acordo com os Quadros 7/8, está cursando Nível Superior e é Professor de LI, ele não pertence à mesma comunidade de fala dos personagens. Seu convívio social é totalmente diferenciado em relação aos personagens da série; no entanto, possui a faixa etária equivalente e mesmo que não seja do mesmo grupo conseguiu encontrar essas equivalências com as expressões e gírias regionais. Neste caso, é correto afirmar que há uma variação linguísticas dessas expressões e gírias, visto que são maneiras diferentes de falar de acordo com cada região e da faixa etária, sexo e classe social do indivíduo. 
- Entrevistado E8

Tabela 9 - Expressões e gírias do Entrevistado 8

\begin{tabular}{|l|l|l|}
\hline São Paulo & Rio de Janeiro & Bahia \\
\hline pega visão & $\begin{array}{l}\text { Olha ostá } \\
\text { acontecendo }\end{array}$ & \\
\hline $\begin{array}{l}\text { aqui não da para ficar } \\
\text { moscando não, parceiro }\end{array}$ & Não pode dar mole & \\
\hline $\begin{array}{l}\text { se não tem um pino para } \\
\text { me salvar mano }\end{array}$ & Tem uma roga ai? & \\
\hline posso marretar com você? & É uma boa & \\
\hline isso é pica parca & Saber o que aconteceu & \\
\hline pegar as fitas contigo & & \\
\hline saquei ele da loja & o que você está fazendo? & \\
\hline qual é dessa fita ai & Tá boa para usar & \\
\hline essa ta o verde heim & Tá legal & \\
\hline ta chave & & \\
\hline $\begin{array}{l}\text { só preciso da peça e do } \\
\text { cavalo }\end{array}$ & Não vai fugir & \\
\hline não vai ramelar & Tá falando merda & \\
\hline ta pousado nas ideias & Vamos ali & \\
\hline te levar para as ideias & Fugir & \\
\hline mete marcha & & \\
\hline
\end{tabular}

Nota-se na Tabela 9, que o E8 não obteve tantas dificuldades em encontrar equivalências com as expressões e gírias regionais. O E8 é um pré-adolescente de apenas 12 anos, do sexo masculino. Mesmo ele não pertencendo à mesma faixa etária dos personagens e nem da mesma comunidade de fala, visto que não está inserido na vida do crime, e mesmo assim conseguiu compreender a maioria das expressões e gírias e transportar para as equivalências de sua região.

- Entrevistado 9

Tabela 10 - Expressões e gírias do Entrevistado 9

\begin{tabular}{|l|l|l|}
\hline São Paulo & Rio de Janeiro & Bahia \\
\hline pega visão & Deu para entender? & \\
\hline $\begin{array}{l}\text { aqui não da para ficar } \\
\text { moscando não, parceiro }\end{array}$ & Aqui não é para dar mole & \\
\hline $\begin{array}{l}\text { se não tem um pino para } \\
\text { me salvar mano }\end{array}$ & $\begin{array}{l}\text { Tem algum bagulho p } \\
\text { mim? }\end{array}$ & \\
\hline posso marretar com você? & Posso trabalhar também? & \\
\hline isso é pica parça & é o máximo/ furada & \\
\hline pegar as fitas contigo & passar as informações & \\
\hline saquei ele da loja & te expulsei do grupo & \\
\hline
\end{tabular}




\begin{tabular}{|l|l|l|}
\hline qual é dessa fita ai & Qual é da situação? & \\
\hline essa ta o verde heim & Essa tá boa & \\
\hline ta chave & tá favorável \\
\hline $\begin{array}{l}\text { só preciso da peça e do } \\
\text { cavalo }\end{array}$ & $\begin{array}{l}\text { Preciso de um bagulho } \\
\text { para dar um corre }\end{array}$ & \\
\hline não vai ramelar & não vai fugir NE & \\
\hline ta pousado nas ideias & tá simulando & \\
\hline te levar para as ideias & Vamos resolver & \\
\hline mete marcha & mete o pé & \\
\hline
\end{tabular}

Na Tabela 10, o E9 é uma mulher de 38 anos. É interessante ressaltar o sexo e a sua faixa etária, pois são distintas das dos personagens. Por ser uma mulher mais velha, estima-se que não compreendesse as expressões e nem as gírias. Contudo, nota-se que a E9 obteve sucesso ao encontrar as equivalências com a sua região, esse fator pode ter ocorrido por ter convívio social com indivíduos que estão inseridos em outra realidade, cuja não é a dela. De acordo com o Quadro 8, o E9 é babá, ou seja, cuida de diversos indivíduos de faixa etárias diferentes, cujo pais podem pertencer a uma comunidade de fala diferente da sua.

\subsubsection{Perguntas}

As quatro perguntas do questionário foram entregues por e-mail para os nove entrevistados, assim sendo seis homens e quatro mulheres. No final do trabalho, terá o Apêndice com a tabela e as perguntas.

Conforme visto na sessão 5.2, a identidades dos entrevistados se manterá em sigilo, revelando apenas a faixa etária, o sexo, a classe social e a região, com o intuito de refletir sobre as variações linguísticas em relação às expressões e gírias da Tabela 1 na sessão 5.2.2, encontradas a partir das transcrições.

Pergunta 1 - Encontrou diferenças no vocabulário em relação a sua região?

O objetivo desta pergunta era de verificar se o entrevistado obteve alguma dúvida em questão de sentido por conta da diferença entre os vocabulários regionais. 
Pergunta 2 - Teve alguma palavra/gíria que não tenha entendido? Se sim, qual?

O intuito foi verificar se as gírias eram de fácil compreensão e identificar quais não eram, visto que são expressões e gírias de outra região e que poderiam dificultar a compreensão.

Pergunta 3 - Teve alguma expressão que não há uma equivalência na sua região? Se sim, qual?

Esta pergunta teve 0 intuito de verificar se o entrevistado encontraria dificuldades ao achar equivalências das expressões e gírias na sua região, caso ele não pertencesse a nenhuma comunidade fala como a dos personagens e caso fosse de convívio social diferente.

Pergunta 4 - Em sua opinião, essas gírias ou expressões estão erradas ou são apenas uma variação linguística daquela região?

Esta pergunta teve como propósito saber a opinião dos entrevistados sobre o que consideravam como errado as expressões e gírias serem tão diferentes do que estão habituados e se entendiam o conceito de variação linguística.

\subsubsection{Entrevistados}

O intuito dessa sessão é de analisar as respostas dos entrevistados conforme as perguntas apresentadas na sessão 5.2.2.1.

No decorrer do texto, serão mostradas as siglas em representação dos entrevistados. A fim de represervar a identidade de cada um, serão representados por siglas, a título de exemplo, Entrevistado 1 por E1 e assim respectivamente, conforme visto na sessão 5.2.1.

Pergunta 1 - Encontrou diferenças no vocabulário em relação a sua região? 


\begin{tabular}{|l|l|}
\hline Entrevistados & Respostas \\
\hline E1 & Sim \\
\hline E2 & Sim \\
\hline E3 & Sim \\
\hline E4 & Sim \\
\hline E5 & Sim \\
\hline E6 & Sim \\
\hline E7 & Sim, muitas. \\
\hline E8 & Várias. \\
\hline E9 & Sim \\
\hline
\end{tabular}

Quadro 10 - Respostas da pergunta 1

No quadro 10 , é possível observar que todos os entrevistados responderam "sim", ou seja, todos encontraram diferenças no vocabulário. Essas diferenças dãose por conta da variedade da língua que cada região possui.

Pergunta 2 - Teve alguma palavra/gíria que não tenha entendido? Se sim, qual?

\begin{tabular}{|l|l|}
\hline Entrevistados & Respostas \\
\hline E1 & Não \\
\hline E2 & Não \\
\hline E3 & Sim, ta chave. \\
\hline E4 & $\begin{array}{l}\text { Sim, várias. Moscando, } \\
\text { pino, fitas, peça e cavalo, ramelar, ideia. }\end{array}$ \\
\hline E5 & $\begin{array}{l}\text { Não } \\
\text { fim. "Posso ir marretar com você?"; "Pegar as } \\
\text { verde heimo"; "Saquei ele da loja"; "essa tá o } \\
\text { "Tá pousado nas ideias"; "Te levar para as } \\
\text { ideias"; "Mete marcha". }\end{array}$ \\
\hline E7 & $\begin{array}{l}\text { Sim, "Só preciso da peça...";"tá posado das } \\
\text { ideias";"saquei ele da loja". }\end{array}$ \\
\hline E8 & $\begin{array}{l}\text { Posso marretar com você; só preciso da peça do } \\
\text { cavalo e saquei ele da loja. }\end{array}$ \\
\hline E9 & Sim, Tá chave e Se não tem um pino... \\
\hline
\end{tabular}


Quadro 11 - Respostas a pergunta 2

No Quadro 11, observa-se uma contraposição nas respostas, 3 entrevistados responderam que "não" obtiveram dificuldade para entender as expressões e gírias. Já os outros entrevistados responderam que "sim", não foi de fácil entendimento algumas gírias e, por conta disso deixaram espaços em branco.

Conforme foi visto na sessão 3.2.2, as gírias pertencem a grupos sociais específicos e, por conseguinte, pessoas que não pertencem a essa comunidade de fala possam não compreender a mensagem a ser transmitida.

Pergunta 3 - Teve alguma expressão que não há uma equivalência na sua região? Se sim, qual?

\begin{tabular}{|l|l|}
\hline Entrevistados & Respostas \\
\hline E1 & $\begin{array}{l}\text { Sim, saquei ele da loja, só preciso da peça e o } \\
\text { cavalo e ta pousado nas ideias. }\end{array}$ \\
\hline E2 & $\begin{array}{l}\text { Sim, só preciso da peça e o cavalo e ta pousado } \\
\text { nas ideias. }\end{array}$ \\
\hline E3 & $\begin{array}{l}\text { Sim, saquei ele da loja, qual é dessa fita ai, só } \\
\text { preciso da peça e do cavalo e ta pousado nas } \\
\text { ideias. }\end{array}$ \\
\hline E4 & $\begin{array}{l}\text { Sim, aqui não da para ficar moscando não, } \\
\text { parceiro, pegar as fitas contigo, qual é dessa fita } \\
\text { ai, essa ta o verde heim, só preciso da peça e do } \\
\text { cavalo e ta pousado nas ideias, não vai ramelar e } \\
\text { te levar para as ideias. }\end{array}$ \\
\hline E5 & $\begin{array}{l}\text { Sim, algumas expressões não existem uma } \\
\text { correspondência direta, mas há semelhança no } \\
\text { uso. Por exemplo: "Essa tá o verde, hein?" a } \\
\text { expressão correspondente e mais próxima é a de } \\
\text { no sentido de estar boa (Tá batendo). }\end{array}$ \\
\hline E6 & $\begin{array}{l}\text { "Saquei ele da loja"; "Só preciso da peça e do } \\
\text { cavalo"; "Tá pousado nas ideias"; "Mete marcha" } \\
\text { e "Te levar para as ideias". }\end{array}$ \\
\hline \begin{tabular}{l} 
Sim "saquei ele da loja" \\
\hline
\end{tabular}
\end{tabular}




\begin{tabular}{|l|l|}
\hline E8 & So preciso da peça e do cavalo. \\
\hline E9 & Sim, “Isso é pica parça” e "Pega a visão" \\
\hline & Quadro 12 - Respostas a pergunta 3 \\
\hline
\end{tabular}

No quadro 12, nota-se que todos os 9 entrevistados obtiveram dificuldades em encontrar equivalências na sua região com as expressões e gírias que são especificas de São Paulo.

Vale ressaltar que as faixas etárias dos entrevistados são distinta das dos personagens, somente o E3/E6/E7 que possui a mesma faixa etária. Contudo, mesmo possuindo a mesma faixa etária o E3/E6/E7obtiveram dificuldades em encontrar equivalência em sua região, por eles não pertencerem à mesma comunidade de fala dos personagens.

A classe social dos entrevistados também por ser distinta das dos personagens influenciou a não compreenderem as expressões e gírias por conta das experiências de vida de cada um.

Pergunta 4 - Em sua opinião, essas gírias ou expressões estão erradas ou é apenas uma variação linguística daquela região?

\begin{tabular}{|l|l|}
\hline Entrevistados & Respostas \\
\hline E1 & $\begin{array}{l}\text { Na minha opinião não são erradas, cada região } \\
\text { tem a sua gíria ou expressão que pessoas de } \\
\text { fora não entendem. }\end{array}$ \\
\hline E2 & $\begin{array}{l}\text { Não acho que são erradas, cada região tem uma } \\
\text { variação linguística diferente, e por isso todos } \\
\text { são interessantes. }\end{array}$ \\
\hline E3 & $\begin{array}{l}\text { Acho que não, cada um tem o seu jeito de falar e } \\
\text { deve ser por conta da região que mora também. }\end{array}$ \\
\hline E4 & $\begin{array}{l}\text { Olha não sei o que é variação linguística, mas o } \\
\text { que eucebi é que cada região tem a sua gíria } \\
\text { e gente de fora as vezes não entende. }\end{array}$ \\
\hline E5 & $\begin{array}{l}\text { Não há erros quando se fala em gírias e } \\
\text { expressões. Cada local tem sua linguagem } \\
\text { própria, cada grupo tem sua própria forma de } \\
\text { comunicação. As expressões colocadas ai, no } \\
\text { caso da Bahia, são expressões utilizadas por um } \\
\text { grupo social de um lugar específico. Dentro da }\end{array}$ \\
\hline
\end{tabular}




\begin{tabular}{|l|l|}
\hline & $\begin{array}{l}\text { própria cidade e do próprio estado, essas } \\
\text { expressões poderão sofrer modificações, } \\
\text { dependendo dos membros que formam cada } \\
\text { grupo. }\end{array}$ \\
\hline E6 & \begin{tabular}{l} 
Apenas uma variação linguística da região. \\
\hline E7
\end{tabular} \\
$\begin{array}{l}\text { Elas estão muito erradas, creio que foram } \\
\text { desenvolvidas a partir da vivência de um grupo } \\
\text { bem específico com práticas bem específicas. } \\
\text { Não caracterizando uma variação da região em } \\
\text { que estão inseridas. }\end{array}$ \\
\hline E8 & $\begin{array}{l}\text { Não entendo o que é isso, mas acho que cada } \\
\text { pessoa fala de uma maneira e por ser de região } \\
\text { diferente muda tudo. } \\
\text { É uma variação linguística de cada região. }\end{array}$ \\
\hline E9 & Quadro 13 - Respostas a pergunta 4 \\
\hline
\end{tabular}

No quadro 13 é possível observar que quase todos entrevistados responderam que a variação linguística não é vista como errada, mesmo que não saibam o conceito teórico. Entenderam que em cada região existe uma maneira especifica de falar determinadas expressões, e que ainda podem variar de acordo com o meio social que estão inseridos, a sua a faixa etária, o sexo e a sua região.

Nota-se que o E7 acredita que as expressões e gírias são erradas, visto que para ele não são as mesmas que está acostumado no cotidiano, por causa dos significados que são totalmente diferentes. Contudo, entende-se que cada região há a sua maneira de falar certos objetos. 


\section{CONSIDERAÇÕES FINAIS}

Este trabalho teve como objetivo de analisar algumas cenas transcritas da Série "Sintonia", a fim de refletir sobre as variações linguísticas e como afetariam o processo tradutório do tradutor.

Antes de qualquer análise, era de suma importância e necessário compreender o que é a Tradução para a sociedade e, especificamente entender o conceito da espécie de Tradução Intralingual. Ademais, foi também preciso entender o conceito da Sociolinguística Variacionista e os fatores que desencadeiam as variações linguísticas.

As análises foram feitas por meio da Sociolinguística Variacionista e da Tradução Intralingual. Este trabalho não teve a intenção de apontar erros e nem de fazer uma Tradução, mas sim de ressaltar as variedades existentes dentro de uma língua. Como foi visto no capítulo 5.

Além disso, este trabalho obteve como objeto de análise um questionário aplicado aos moradores de estados diferentes sobre as expressões e gírias retirados da série, a fim de refletir sobre as variações linguísticas distintas entre os estados de São Paulo, Rio de Janeiro e Bahia.

A lingua é objeto de estudo tanto da Sociolinguística quanto da Tradução, é o que correlaciona ambas. Mesmo sendo analisadas sobre formas distintas, visto que o tradutor se atenta para as línguas fonte e meta de um texto, já o sociolinguista se atenta para a língua em seu uso em tempo real. Por conta disso, o papel do tradutor, apresentado na sessão 2.2.2, é de coletar tais informações sobre as línguas em questão. O papel do sociolinguista é de gerar informações sobre a língua, através do contexto situacional de seu falante, conforme apresentado na sessão 3.2.3.

A partir disso, foi observado que o sociolinguista obtém dificuldades quando é necessário realizar uma transcrição da língua falada para a lingua escrita, visto que são distintas, conforme postulado por Paganine; Fonseca (2005).

Foi observado, que a dificuldade do tradutor ao se deparar com uma Tradução Intralingual, é justamente com as variações existentes da língua. Em seu corpus, o tradutor terá que coletar quaisquer informações sobre as diferenças entre os dialetos regionais, as expressões e gírias que são especificas de determinadas comunidades de fala, para que seu objetivo na tradução seja alcançado, ou seja, que o leitor compreenda a mensagem do texto. 
Balizados pelos entendimentos apresentados anteriores ao decorrer deste trabalho, vimos que há um preconceito linguístico relacionado ao português não padrão falado no Brasil. Um português que não corresponde as normais gramaticais; no entanto, que é bastante pronunciado por certas comunidades de fala, especialmente por aqueles de baixa escolaridade ou influenciados pelo meio social em que se vive. Além disso, que não há uma língua única, visto que ela é dotada de variações.

Neste trabalho, foi observado que através da Série "Sintonia", que apresenta jovens que se comunicam por meio deste português não padrão. Foi por meio desta análise aos personagens que foi possível entender que há sim ainda um preconceito linguístico relacionado a esse estilo da linguagem não padronizada, mas também que esse estilo é ocasionado por inúmeros fatores linguísticos e sociais.

No capítulo 5, através das análises das cenas transcritas e das expressões e gírias retiradas do primeiro episódio da série que em cada região existe a sua maneira específica de falar determinadas expressões, devido à variação linguística do Português. Essa variação ocorre por conta de alguns fatores, que vimos na sessão 3.2.1, que de acordo com a faixa etária, região, classe social e sexo dos indivíduos a mensagem possa a ser não compreendida, cujo, a comunidade de fala entre os falantes sejam distintas.

As análises tanto das cenas e quanto das expressões e gírias foram com o intuito de refletir sobre a variação linguística do português. Que a língua portuguesa mesmo sendo a língua oficial do Brasil, ela não pode ser considerada como única, visto que cada região há seus dialetos específicos. Além disso, a língua ainda pode variar de acordo com o meio social de seu falante. 


\section{REFERÊNCIAS BIBLIOGRÁFICAS}

ALVES, Fábio; MAGALHÃES, Célia; PAGANO, Adriana. Traduzir com Autonomia: Estratégia para o Tradutor em Formação. Belo Horizonte, MG: Contexto, 2003.

ANJOS, Flavius Almeida dos. 0 inglês como língua franca global da contemporaneidade: em defesa de uma pedagogia pela sua desestrangeirização e descolonização. Revista Letra Capital, v. 1, n. 2, jul./dez. 2016, p. 95-117. Disponível em:<http://periodicos.unb.br/index.php/lcapital/article/download/8590/7151>.

Acesso em: 20 abr. 2020.

ARROJO, Rosemery. Oficina de Tradução: A teoria na prática. São Paulo: Ed. Ática, 1986.

ARROJO, R. (org.) O signo desconstruído: implicações para a tradução, a leitura e o ensino. Campinas/SP: Pontes, 1992.

ARROJO, R. Tradução, desconstrução e psicanálise. Rio de Janeiro: Imago, 1993.

BAGNO, M. Nada na língua é por acaso: por uma pedagogia da variação linguística. São Paulo: Parábola, 2007.

BAKHTIN, M. Marxismo e filosofia da linguagem. 5. ed. São Paulo: Hucitec, 1990.

BALLARD, Michel. Antigas Premissas. In: MARTINS, Marcia A. P. (Org.). Tradução e Multidisciplinaridade. Rio de Janeiro: Lucerna, 1999.

BENVENISTE, E. Estrutura da língua e estrutura da sociedade. In: Problemas de linguística geral II. São Paulo: Cia. Editora Nacional/EDUSP, 1989.

BESSA, Waldemberg Araújo. Gíria: uma perspectiva em uso em sala de aula. 2013. 114 f. Dissertação (Mestrado em Letras) - Centro Universitário Ritter dos Reis, Porto Alegre. Disponível em:

$<$ https://biblioteca.uniritter.edu.br/imagens/035UNR89/0000E5/0000E544.pdf>.

Acesso em: 05 nov. 2020.

BORDINI, Marcella; GIMENEZ, Telma. Estudos sobre inglês como língua franca no Brasil (2005-2012): uma metassíntese qualitativa. Signum: Estudos da Linguagem, [S.I.], v. 17, n. 1, p. 10-43, jun. 2014. ISSN 2237-4876. Disponível em: $<$ http://www.uel.br/revistas/uel/index.php/signum/article/view/17389>. Acesso em: 20 abr. 2020.

BORGES, Nara Rubia Martins. A descaracterização da gíria nos blogs. Dissertação (Pós-Graduação em Linguística) - Universidade Federal de Uberlândia, Uberlândia, 2007. Disponível em: $<$ https://repositorio.ufu.br/bitstream/123456789/15320/1/Nara.pdf>. Acesso em: 06 nov. 2020. 
BORTONI-RICARDO, Stella Maris. Manual da Sociolinguística. São Paulo: Contexto, 2014.

BLOOMFIELD, Leonard. Le langage. Paris: Payot, 1970.

BRITTO, Paulo H. A tradução literária. Rio de Janeiro: Civilização Brasileira, 2012.

CALVET, Louis-Jean. Sociolinguística: uma introdução crítica. São Paulo: Parabola, 2002.

CÂMARA JR, Joaquim Mattoso. Contribuição à estilística portuguesa. 3. ed. Rio de Janeiro: Ao Livro Técnico, 1978.

História da Linguística. 3. ed. Petrópolis: Vozes, 1979.

Estrutura da língua portuguesa. 14. ed. Petrópolis: Vozes, 1984.

Padrão, 1985.

História e Estrutura da Língua Portuguesa. 4. ed. Rio de Janeiro:

CAMPOS, Geir. O que é tradução. São Paulo: Editora Brasiliense, 1987.

CASTILHO, Ataliba de. Como as línguas nascem e morrem? O que são famílias linguísticas?. Museu da Língua Portuguesa: Estação da luz. São Paulo.

Disponível em: <http://museudalinguaportuguesa.org.br/wpcontent/uploads/2017/09/Como-as-linguas-nascem-e-morrem.pdf>. Acesso em: 4 set. 2014.

CATFORD, J. C. Uma Teoria Linguística da Tradução: um ensaio de linguística aplicada. São Paulo: Cultrix, 1980.

CEZARIO, Maria M; S Votre. Manual de Linguística. São Paulo: Contexto 1, 141155, 2008.

CICERON. Du meilleur genre d'orateurs. Texte établi et traduit par Henri Bornecque. Paris: Les Belles Lettres, 1921.

CHOMSKY, A. N. Aspects of the Theory of Syntax. Cambridge, Massachusetts, the MIT Press, 1965.

. Lectures on Government and Binding. Dordrecht: Foris Publications, 1988.

COLEMAN, Julie. The Life of Slang. Estados Unidos: Oxford University Press, 2012.

CORACINI, M. J. R. F. O Sujeito Tradução entre a "sua" Língua e a Língua do Outro. Cadernos de tradução, Florianópolis, n 16. p. 9-24,2005. 
COSTA et al. Linguística. In: MARTELOTTA, Mário Eduardo. (Org.). Manual de linguística. 2. ed. São Paulo: Contexto, 2011.

CRYSTAL, D. English as a global language. Cambridge University Press, 2a ed. 2003. Editor, 1988.

Dicionário de linguística e fonética. 3 ed. Rio de Janeiro: Jorge Zahar

DAYRELL, Juarez. O rap e o funk na socialização da juventude. Educ. Pesqui. São Paulo, v. 28, n. 1, p. 117-136, jun. 2002. Disponível em:

$<$ http://www.scielo.br/scielo.php?pid=S151797022002000100009\&script=sci arttext $>$ . Acesso em: 11 mar. 2020.

DIAS, Fátima Regina da Silva Ribeiro. Tradução Intralingual e Tradaptação numa Empresa de Legendagem. 268 f. Dissertação (Mestrado em Tradução Área de Especialização em Inglês) - Faculdade de Ciências Sociais e Humanas, Universidade de Lisboa, Lisboa, 2013. Disponível em:

$<$ https://run.unl.pt/bitstream/10362/10655/1/Fatimadias.pdf>. Acesso em: 05 mar. 2020.

DRYDEN, John; KINSLEY, James. The Complete Works of Jhon Dryden. Oxford University Press, 1956, vol. 1, p. 182.

DUBOIS, Jean et al. Dicionário de linguística. 8. ed. São Paulo: Cultrix, 2001.

ECO, Umberto. Quase a mesma coisa. Rio de Janeiro: Record, 2007.

FIORIN, José Luiz. Introdução á Linguística. 5. ed. São Paulo: Contexto, 2007.

FURLAN, M. Brevíssima História da Teoria da Tradução no Ocidente, I

Romanos. Cadernos de Tradução, Florianópolis, n 8. p. 1128, 2001.

GONÇALVES, J. L. V. R.; Machado, I. T. N. Um panorama do ensino de tradução e a busca da competência do tradutor. Cadernos de tradução, Florianópolis, n. 17, p. $45-69,2006$.

GREUEL, M. V. Reflexões Fenomenológicas sobre a Teoria da Tradução. Cadernos de Tradução, Florianópolis, n 1. p. 28-36, 1996.

JACOBSON, R. Aspectos lingüísticos da tradução. In: Lingüística e Comunicação. São Paulo: Cultrix, p. 63-72, 1971.

JEROME,Saint. L VII, Ad Pammachium de optima genere interpretandi / L VII, a Pammachius as meilleure méthode de traduction. Texte établi et traduit par Jerôme Labourt, Lettre, T. III. Paris: Les Belles Lettres, p. 53-73, 1953.

JUNIOR, Anderson Xavier Duarte. A Tradução da gíria nas legendas da primeira temporada da Série Insecure da HBO. Revista do ISAT. vol. 12, ed. 1, ago. 2020.Disponível em: 
<https://www.revistadoisat.com.br/numero12/06 Anderson Traducao Giria.pdf>. Acesso em: 26 out. 2020.

KONDIZILA. Sintonia Série da Netflix.Direção: Guilherme Quintella, Felipe Braga. 2019.

Disponível em:

$<$ https://www.netflix.com/watch/80217245?trackld=14277281\&tctx=0\%2C0\%2C7d47 b2ed-e205-4a64-9fc0-338362cc4fd3-12658162\%2C\%2C\&ad=true>. Acesso em: 24 nov. 2019.

KLEIN, W. "Was kann sich die Übersetzungswissenschaft von der Linguistikerwarten?", in: Zeitschrift für Literaturwissenschaft und Linguistik, Vandenhoek \& Ruprecht, 1992, n84, pp.104-123.

KRIEGER, Maria da Graça; FINATTO, Maria José Bocorny. Introdução à Terminologia. São Paulo, Contexto, 2004.

LABOV, W. Where does the Linguistic variable stop? A response to Beatriz Lavandera. In: Sociolinguistic Working Papers, 1978, p. 43-88.

. Building on Empirical Foundations. In: LEHMANN, W. \&MALKIEL, Y. Perspectives on Historical Linguistics. Amsterdam: John Benjamins, 1982, 17-92.

Padrões sociolinguísticos. Tradução de Marcos Bagno, Maria Marta Pereira Scherre, Caroline Rodrigues Cardoso. São Paulo: Parábola Editorial, 2008.

LYONS, John. Lingua(gem) e Linguística: uma introdução. Tradução: Marilda Winker Averburg; Clarisse Sieckenius de Souza. Rio de Janeiro: LTC, 2009.

MARQUES, Marcio dos Santos. Comparação entre a Tradução para Dublagem e a Tradução para Legendagem do filme Madagascar. Revista do Isat, São Gonçalo, RJ, v. 5 ed. 1, dez, 2015. Disponível em:

$<$ https://www.revistadoisat.com.br/numero5/012 Comparacao entre a traducao Ma rcio Marques.pdf>. Acesso em: 26 nov. 2019.

MENDES, Eliana Amarante de Mendonça. Processos de Tradução Intralingual. Universidade Federal de Uberlândia, Uberlândia, 2009. Disponível em: $<$ http://www.leffa.pro.br/tela4/Textos/Textos/Anais/ABRALIN 2009/PDF/Eliana\%20\% 20Amarante\%20de\%20Mendon\%C3\%A7a\%20MENDES\%20-\%20ok.pdf>. Acesso em: 06 mar. 2020.

MOLLICA, M. C. Fundamentação teórica: conceituação e delimitação. In: MOLLICA, M. C. e BRAGA, M. L. (orgs.) Introdução à sociolinguística: o tratamento da variação. São Paulo: Contexto, 2003. p. 9-14.

MOUNIN, Georges. Os Problemas Teóricos da Tradução. São Paulo: Cultrix, 1975. 
MOURA, Gehilde Reis Paula de. Revisão linguística: processo de tradução intralingual. Educação \& Tecnologia, [S.I.], v. 19, n. 1, fev. 2015. Disponível em: $<$ https://periodicos.cefetmg.br/index.php/revista-et/article/view/595>. Acesso em: 12 mar. 2020.

MURATA, Y. (1996). Translation as spiritual community. In: Tradterm: Revista do Centro Interdepartamental de Tradução e Terminologia - FFLCH-USP, no 3, p. 66-75.

NEWMARK, P. (1988). A texbook of translation. London:

Prentice Hall.

NIDA, E. Language, culture and translating. Shanghai: Foreign Language Press. [Tradução nossa], 1993.

NORMAN, k. Denzin; YVONNA, S. Lincoln. O planejamento da pesquisa qualitativa: teorias e abordagens. Tradução: Sandra Regina Netz. $2^{a}$ ed. Porto Alegre: Artmed, 2006.

OUSTINOFF, Michaël. La Traduction. (Que sais-je?) Paris, Presses Universitaires de France, 2007. Capítulo II. [Tradução nossa.] [Revisado em 13 fev. 2013.]

PAES, J. P. Tradução: a ponte necessária. São Paulo: Ática, 1990.

PAGANINE, Carolina; FONSECA, Ester. Algumas considerações sobre variação linguística e tradução literária. Revista Non Plus, n. 7, p. 67-77, 2015.

Disponível em: <http://www.revistas.usp.br/nonplus/article/view/106913>. Acesso em: 29 out. 2020 .

PRETI, Dino. Sociolinguística: Os níveis de fala. São Paulo: Cia. Ed. Nacional, 1982.

. A gíria e outros temas. São Paulo: T. A. Queiroz, 1984.

. Norma e variedades lexicais urbanas. In: CASTILHO, A. T. de (org.)

Português culto falado no Brasil. Campinas/SP: Editora da Unicamp, 1989. p. 157-168.

. Fala e escrita em questão. São Paulo: Humanitas, 2006.

Dicionários de gíria. São Paulo: Alfa, 2000, n. 44, p. 57-73.

RÓNAI, Paulo. A Tradução Vivida. 2ª ed. Rio de Janeiro: Nova Fronteira, 1981. . Escola de Tradutores. São Paulo: EDUSC, 2002.

SAUSSURE, Ferdinand de. Curso de linguística geral. 28 ed. São Paulo: Cultrix, 2007. 
SEIDLHOFER, B. Closing a conceptual gap: the case for a description of English as a lingua franca. International Journal of Applied Linguistics, Oslo, v. 11, n. 2, p. 133-158, 2001.

SILVA, Julia Izabelle. Do mito da língua única à política do plurilinguismo: desafios na implementação de leis de cooficialização linguística em municípios brasileiros. Matraga - Revista do Programa de Pós-Graduação em Letras da UERJ, [S.I.], v. 23, n. 38, jun. 2016. Disponível em: <https://www.epublicacoes.uerj.br/index.php/matraga/article/view/20751/18165>. Acesso em: 12 mar. 2020.

SILVA, Alessandra Freitas da. Gíria: linguagem ou vocabulário?. Revista Philologus, Rio de Janeiro, v. 14, n. 41, p. 35-48, maio/ago. 2008. Disponível em: $<$ http://filologia.org.br/revista/41/giria linguage ou vocabulario.pdf>. Acesso em: 06 nov. 2020.

SILVEIRA, B. A Arte de Traduzir. São Paulo: Melhoramentos, 1972.

SNELL-HORNBY, M. (1988). Translation studies: an integrated approach. Amsterdam: John Benjamins Publishing Company.

STUPIELLO, E. N. A. O Ideal e o Real no Ensino Universitário da Tradução. Cadernos de tradução, Florianópolis, n. 17, p. 129-139, 2006.

TARALLO, F. A pesquisa sociolinguística. São Paulo, Ática, 1994.

TROTTA, Felipe da Costa. "O FUNK NO BRASIL CONTEMPORÂNEO: Uma Música Que Incomoda." Latin American Research Review. v.51, n. 4, 2016. Disponível em: <https://www.jstor.org/stable/44985919?seq=1>. Acesso em: 07 mar. 2020.

VALADARES, Flavio Biasutti.Revistando a noção de gírias: do conceito à dicionarização. Revista Dominus de Linguagem. vol. 5, n-1, 2011. Disponível em: $<$ http://www.seer.ufu.br/index.php/dominiosdelinguagem/issue/view/649>. Acesso em: 29 out. 2020.

VEGA, Miguel Ángel. ed. Textos Clásicos de Teoría de la Traducción. Madrid: Cátedra, 1994. [tradução nossa]

VINAY, J. P. \& Darbelnet, J. (1977). Stylistique comparée du français et de l'anglais: méthode de traduction.Paris:Didier. (Nova edição revista e corrigida. Primeiraedição: 1958).

WEINREICH, U.; LABOV, W. \& HERZOG, M. Fundamentos empíricos para uma teoria da mudança linguística. São Paulo: Parábola, 2006. 


\section{APÊNDICE}

\section{Questionário dos Entrevistados ${ }^{3}$}

Nome:

Idade:

Cidade:

Estado:

Escolaridade:

Profissão:

O objetivo deste questionário é de analisar as diferenças culturais dentro da língua portuguesa devido às variações linguística através de expressões e gírias retiradas do primeiro episódio da Série "Sintonia".

\section{1- Preencha a tabela de acordo com a sua região:}

\begin{tabular}{|l|l|l|}
\hline São Paulo & Rio de Janeiro & Bahia \\
\hline $\begin{array}{l}\text { pega visão } \\
\text { moscando não, parceiro }\end{array}$ & & \\
\hline $\begin{array}{l}\text { se não tem um pino para } \\
\text { me salvar mano }\end{array}$ & & \\
\hline $\begin{array}{l}\text { posso marretar com } \\
\text { você? }\end{array}$ & & \\
\hline isso é pica parça & & \\
\hline pegar as fitas contigo & & \\
\hline saquei ele da loja & & \\
\hline qual é dessa fita ai & & \\
\hline essa ta o verde heim & & \\
\hline ta chave & & \\
\hline $\begin{array}{l}\text { só preciso da peça e do } \\
\text { cavalo }\end{array}$ & & \\
\hline não vai ramelar & & \\
\hline ta pousado nas ideias & & \\
\hline te levar para as ideias & & \\
\hline mete marcha & & \\
\hline
\end{tabular}

\footnotetext{
${ }^{3}$ O questionário foi o mesmo tanto para os entrevistados do RJ quanto da BA.
} 


\section{2 - Respondas as perguntas:}

1 - Encontrou diferenças no vocabulário em relação a sua região?

2 - Teve alguma palavra/gíria que não tenha entendido? Se sim, qual?

3 - Teve alguma expressão que não há uma equivalência na sua região? Se sim, qual?

4 - Em sua opinião, essas gírias ou expressões estão erradas ou é apenas uma variação linguística daquela região? 